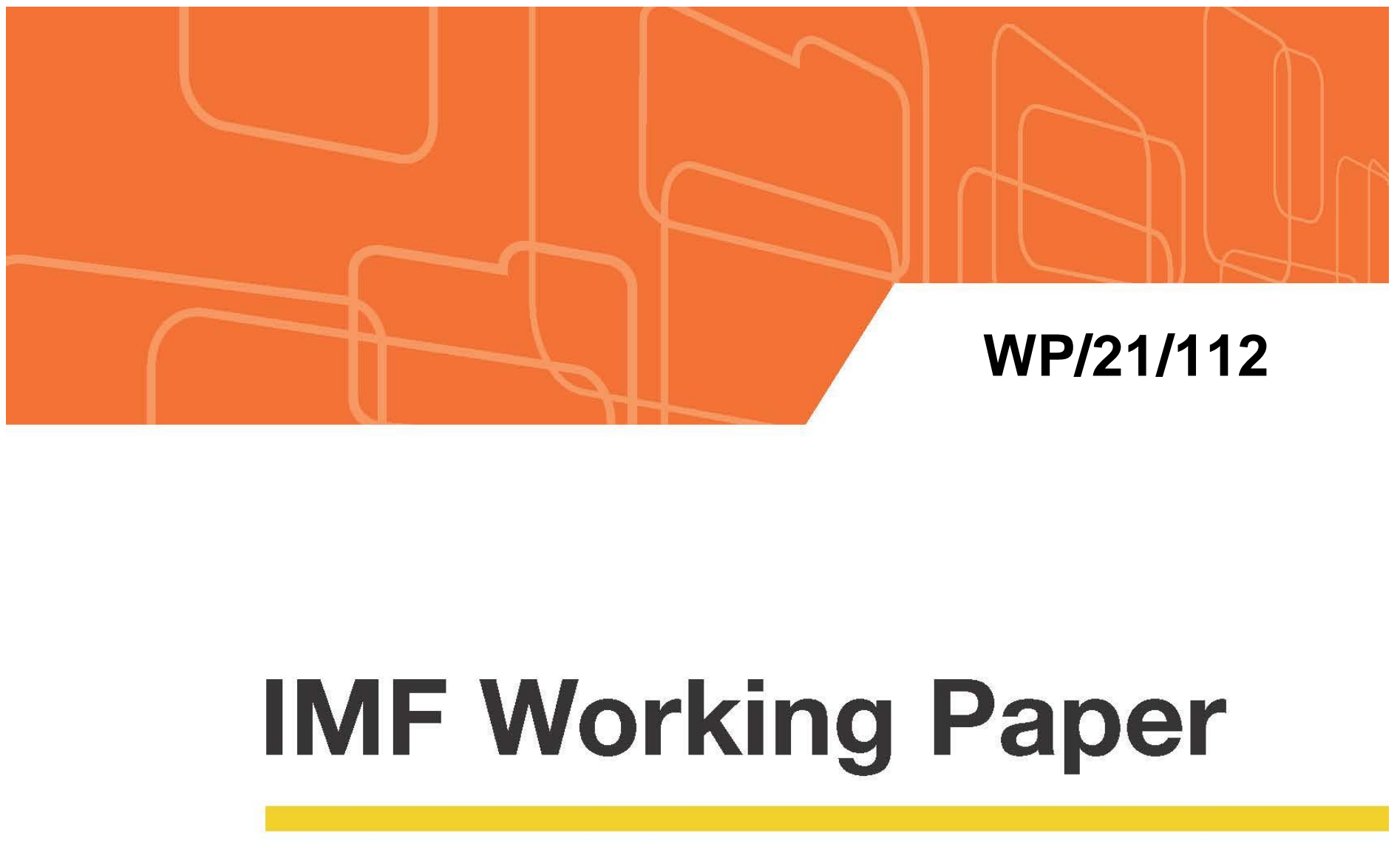

\title{
Limits to Private Climate Change Mitigation
}

by Dalya Elmalt, Deniz Igan, and Divya Kirti

IMF Working Papers describe research in progress by the author(s) and are published to elicit comments and to encourage debate. The views expressed in IMF Working Papers are those of the author(s) and do not necessarily represent the views of the IMF, its Executive Board, or IMF management. 


\title{
IMF Working Paper
}

Research Department

\section{Limits to Private Climate Change Mitigation}

Prepared by Dalya Elmalt, Deniz Igan, and Divya Kirti ${ }^{1}$

Authorized for distribution by Deniz Igan and Maria Soledad Martinez Peria

April 2021

\section{IMF Working Papers describe research in progress by the author(s) and are published to elicit comments and to encourage debate. The views expressed in IMF Working Papers are} those of the author(s) and do not necessarily represent the views of the IMF, its Executive Board, or IMF management.

\begin{abstract}
As climate change looms larger, many look to sustainable investing that incorporates environmental, social, and governance (ESG) concerns as part of the way forward. To assess scope for ESG-conscious investing to achieve climate change goals, we explore the link between emissions growth and ESG scores using firm-level data for the largest emitters around the world. Discouragingly, our analysis uncovers at best a weak relationship: firms with better ESG scores do display somewhat slower emissions growth but this link is substantially attenuated and no longer statistically significant if we limit attention to within-country or within-firm variation. Our findings suggest limited scope for sustainable investing strategies conditioned solely on ESG indicators to meaningfully help mitigate climate change and, more broadly, underscore the need to continue to build consensus towards effective economy-wide policies to address climate change.

JEL Classification Numbers: G30, Q54

Keywords: Sustainable investing, ESG, major upstream emitters, climate change Authors’ E-Mail Addresses: delmalt@imf.org, digan@imf.org, dkirti@imf.org
\end{abstract}

\footnotetext{
${ }^{1}$ We thank Malcolm Baker, John Campbell, Stijn Claessens, Torsten Ehlers, Sole Martinez Peria, Benoit Mohon, Lakshmi Naaraayanan, Marcus Opp, Luis Viceira, Adi Sunderam, Federica Zeni, and seminar participants at the IMF for helpful discussions. We are gra teful to Richard Heede at the Climate Accountability Institu te for sharing data with us.
} 


\section{Introduction}

As climate change looms ever larger (Intergovernmental Panel on Climate Change (IPCC) 2014, IPCC 2018b, Lenton, Rockström, Gaffney, Rahmstorf, Richardson, Steffen \& Schellnhuber 2019, Weitzman 2009), economists have coalesced around the need for climate policies centering around Pigouvian taxes cushioned by transfers to vulnerable households (International Monetary Fund 2020, Kneese 1971, Solow 1972) 1 However, carbon taxes and related policies face deep political constraints (Nordhaus 2015, Gillingham \& Stock 2018, Pahle, Burtraw, Flachsland, Kelsey, Biber, Meckling, Edenhofer \& Zysman 2018). As a complement to policies directly targeting carbon emissions, many look to sustainable investing - increasingly identified with the incorporation of environmental, social, and governance (ESG) concerns in investment strategies - as part of the way forward (Krueger, Sautner \& Starks 2020, Matos 2020, International Monetary Fund 2019, Starks 2020, Hong, Wang \& Yang 2021). In this paper, we examine whether such market forces can help make meaningful progress in addressing climate change.

While climate change is a global challenge, much of the global stock of carbon emissions can be traced to a remarkably small set of firms. Figure 1 shows that just 96 firms located upstream in production chains reliant on carbon emissions (largely fossil fuel producers) have accounted for 70 percent of global carbon emissions since 1850 (Heede 2014a, Heede 2014b). This striking concentration motivates us to focus on the potential for ESG investing to shift production incentives within this important set of firms.

To assess scope for ESG-conscious investing to affect production decisions, we combine firmlevel data on emissions for large emitters through 2017 with data on ESG metrics and other firm characteristics. Some large emitters are directly controlled by national governments: these firms, accounting for 22 percent of global emissions since 1850, are largely unaffected by sustainable investing. We study a panel covering 52 investor-owned firms in 20 countries accounting for close to 30 percent of global emissions since 2002. ${ }^{2}$ Industry-level comparisons suggest that these firms

\footnotetext{
${ }^{1}$ See a 2019 statement by a group of prominent economists in support of carbon taxes with lump sum rebates.

${ }^{2}$ Our sample of 96 firms consists of 32 state-owned enterprises and 64 investor-owned firms. We focus on a sample of 52 firms for which at least ten years of data are available. We obtain similar results from using a panel
} 
are attuned to ESG considerations: they receive better overall ESG and environmental ratings than listed firms in other industries 3

In principle, concerned investors wishing to shift production incentives for these large investorowned emitters could strongly condition their investment decisions on ESG indicators (Oehmke \& Opp 2020) [4 A basic prerequisite for such a strategy to be effective is that changes in these firms' contributions to climate change need to be reflected in ESG scores. Large emitters that cut - or promise to cut - their emissions would then receive high ESG scores, attract fresh investments from ESG investors, and lower their cost of capital. Conversely, firms that continue to make 'dirty' investments, penalized via poor ESG scores, would face higher costs of capital due to waning interest from ESG investors. This dynamic could generate a virtuous cycle in which firms with higher ESG scores have slowing emissions and vice versa.

Discouragingly, ESG scores do not appear to capture differences in emissions growth across large emitters. ESG scores and emissions growth do vary significantly within the panel. The interquartile range of emissions growth across large emitters is 10.4 percent (meaningful even in comparison to countries' Paris agreement pledges to slow emissions growth). However, ESG scores appear largely unrelated to emissions growth (Figure 2). This lack of relationship does not depend on whether we focus on the overall panel or specifically on large changes in ESG scores or emissions.

More systematic analysis uncovers at best a weak relationship between ESG scores and emissions growth. Our baseline regressions examine the link between emissions growth and ESG ratings at the firm-year level, controlling for firm characteristics and macroeconomic conditions. We include year fixed effects to capture global trends such as shifts in demand and supply in production chains dependent on carbon emissions. Large emitters with better ESG scores do display somewhat slower emissions growth. This link is largely tied to scores on the governance of 61 firms (for which ESG data is available) including all firm-years available.

${ }^{3}$ See Appendix Figure A.1.

${ }^{4}$ Broccardo, Hart \& Zingales (2020) refer to this approach as exit. Alternatively, shareholders could also use voting power (their 'voice') to influence emitting firms' actions. As many investors focused on climate change risks pay attention to ESG ratings (Krueger et al. 2020, Matos 2020), our results are relevant for both approaches. 
pillar of ESG rather than the environmental pillar.

The link between ESG scores and emissions growth is substantially attenuated - and no longer statistically significant - if we rely on within-country or within-firm variation. The lack of a within-firm connection is important: large emitters that reduce (increase) emissions growth do not appear to be consistently rewarded (penalized) by better (worse) ESG scores. While our baseline approach focuses on emissions growth, we obtain similar results based on changes in emissions scaled by assets or revenue.

Further analysis reveals that, to the extent that there is a connection between ESG ratings and emissions growth, its scale is not meaningful relative to the climate change problem. Ongoing rapid growth in ESG investing may incentivize large emitters to improve their ESG scores by cutting their emissions. Could a large collective improvement in ESG scores across major emitters be interpreted as a strong positive signal of the impact of ESG investing? Unfortunately, the weak link with emissions growth means that, even with our largest estimates, the associated reduction in emissions would do little to meaningfully help mitigate climate change. According to scenarios prepared by the IPCC (2018a), with emissions growing in line with historical trends, in just 14 years the odds that warming can be limited to 1.5 degrees Celsius would be worse than even. Allocated proportionately, even a two standard deviation improvement in ESG scores would correspond to slowing emissions growth enough to buy just two more years before this climate objective would be out of reach.5

ESG investing has grown dramatically in recent years, in large part motivated by growing attention to climate change (see Matos (2020), Starks (2020), and Cornell \& Damodaran (2020) for engaging reviews of the burgeoning academic literature on ESG investing) ${ }^{6} 7$ Signatories to the Principles for Responsible Investing — with some US $\$ 80$ trillion in assets under management in 2019-report that ESG considerations are integrated into investment decisions for three-

\footnotetext{
${ }^{5}$ We reach similar conclusions if we focus on other climate objectives or consider a range of other climate models.

${ }^{6}$ See Giglio, Kelly \& Stroebel (2020) for a broader review of work at the intersection of climate change, macro-finance, and financial economics.

${ }^{7}$ Potentially self-fulfilling perceptions that ESG metrics are directly relevant for financial performance may also be an important driver (Amel-Zadeh \& Serafeim 2018, Gibson, Krueger \& Mitali 2020).
} 
quarters of assets under management (Matos 2020). Many of these investors appear to actively target portfolio allocations towards firms with higher ESG scores (Gibson, Glossner, Krueger, Matos \& Steffen 2020). Particularly relevant for our work, large asset managers cognizant of climate risks report that they are strongly focused on firms' ESG ratings (Krueger et al. 2020). Indeed, the cost of capital rises with prominent shifts in the global climate policy discussion for firms with poor environment pillar scores (Seltzer, Starks \& Zhu 2020).

However, our findings suggest that there is limited scope for sustainable investing strategies conditioned (solely) on ESG indicators to meaningfully shift production incentives for large emitters. ESG scores overall — as well as environment pillar scores - do not link tightly with emissions growth for major emitters, suggesting that these scores may not deliver what investors expect them to. This could reflect fundamental constraints with data availability due to the lack of consistent reporting. The multidimensional nature of the ESG approach may also place constraints: indeed, several researchers have noted disagreements across providers of ESG scores (Berg, Koelbel \& Rigobon 2020, Gibson, Krueger \& Schmidt 2021, International Monetary Fund 2019, Christensen, Serafeim \& Sikochi 2019), albeit with smaller disagreements about environment pillar scores than on other pillars (Gibson et al. 2021). Some investors may also not be aware that important components of ESG scores often compare firms to competitors in the same industry, providing relative rather than absolute rankings.

Many commentators and policymakers have called for more robust disclosure requirements for climate risk (International Monetary Fund 2019); systemic jurisdictions such as the UK have introduced comprehensive requirements and the International Organization of Securities Commissions is encouraging the development of global sustainability reporting standards. More attention to consistently reported measures directly connected to contributions to climate change is likely to help (see e.g. Ehlers, Mojon, Packer \& da Silva (2020)). While consistent reporting standards and requirements for all firms would be valuable, sustained efforts from third-party researchers mean that data is not a key constraint for the important set of firms we study: Investors concerned about climate change can directly focus on emissions growth to evaluate 
both these firms and asset management products that incorporate them. Naaraayanan, Sachdeva \& Sharma (2020) show that some sophisticated investors have already conditioned activism campaigns on measures of potential future emissions rather than ESG scores. Such approaches do continue to face important challenges, highlighting the need to continue to build consensus towards effective economy-wide policies to address climate change ${ }^{8}$

While there is now a large literature on ESG investing, the literature examining firm-level emissions is more sparse as researchers have found obtaining comprehensive datasets, with comparable coverage for large panels of firms with reasonable time series, challenging. Three recent studies rely on emissions data collected by the US Environmental Protection Agency: Naaraayanan et al. (2020) show that activist campaigns can help reduce ancillary toxic and greenhouse gas emissions, but find no effect on carbon emissions or production; Ivanov, Kruttli \& Watugala (2020) explore the impact of new regulations on bank lending terms; and Shive \& Forster (2020) study the link between ownership structures and emissions.9 ${ }^{9}$ Several researchers have worked with voluntary disclosures collected by the Carbon Disclosure Project, examining implications for financial markets as well as firms' own actions (Ilhan, Sautner \& Vilkov 2021, Bolton \& Kacperczyk 2020a, Bolton \& Kacperczyk 2020b, Ioannou, Li \& Serafeim 2016).

While focused on a small set of firms, our data provides important advantages. It is not based on voluntary disclosures, and covers all upstream firms, across countries, with globally relevant contributions to climate change. Avoiding reliance on voluntary disclosures is crucial when considering variation in emissions within industries - variation that is masked with imputations at the industry level. Moreover, our data includes estimates of emissions generated downstream from the set of large emitters we study (our data includes estimates of Scope 1 and Scope 3 emissions; Scope 2 emissions are excluded to avoid double counting). Past work has tended to include only emissions directly tied to production and inputs (Scope 1 and 2).

Our work is also related to a broader literature that asks what objectives firms should focus on

\footnotetext{
${ }^{8}$ Challenges include accounting for how sustainable investing affects capital allocation in equilibrium (Green \& Roth 2021) and important innovations from historically large emitters (Cohen, Gurun \& Nguyen 2020).

${ }^{9}$ Other activism campaigns targeted at large listed firms with high emissions have also received media coverage.
} 
and how they should be disciplined to meet these objectives. Many begin from the contractarian perspective that companies exist for the benefit of shareholders (Berle 1930). However, the proposition that this translates to profit maximization (Friedman 1970), while largely accepted for many decades, has been challenged in recent years (Hart \& Zingales 2017, Broccardo et al. 2020) 10 Taking an objective as given, good governance helps ensure that companies actually pursue this objective (Shleifer \& Vishny 1997). Indeed, governance is a central element of the ESG approach. Better governance may have a constructive role to play: the link between better ESG ratings and slower emissions growth, while weak, is largely driven by firms rated as having better management practices. Moreover, institutional ownership may help tighten the connection between ESG ratings and emissions growth.

The remainder of the paper is structured as follows. Section 2 describes the data. Sections 3 and 4 turn to empirical results and magnitudes. Section 5 concludes.

\section{Data}

Our analysis explores the relationship between carbon dioxide emissions and ESG ratings at the firm level. In this section, we describe the sources and coverage of each data series. We complement these series with controls at the firm and country level. In line with the corporate finance literature, firm-level variables include firm size (as measured by total assets), revenue, leverage (as measured by the debt-to-asset ratio), fixed asset growth, and the fraction of shares held by institutional investors. We also incorporate major macroeconomic indicators including GDP growth, inflation, and unemployment rates. We obtain these series from Thomson Reuters Eikon, Capital IQ, the IMF's World Economic Outlook, the World Bank, and CEIC.

\footnotetext{
${ }^{10} \mathrm{~A} 2019$ statement by the Business Roundtable, a group of prominent US CEOs, arguing that companies should incorporate all stakeholders' concerns, has attracted much attention. See Zingales, Kasperkevic \& Schechter (2020) for a lively volume summarizing a variety of perspectives.
} 


\subsection{Emissions data}

Our main variable of interest is carbon dioxide emissions at the firm level. We briefly describe this data here, and refer readers interested in further details to Heede (2014a) and Heede (2014b).

We use data on carbon dioxide emissions compiled by the Climate Accountability Institute (CAI) - a nonprofit organization engaged in research and education on anthropogenic climate change. The organization compiles information on daily production of fossil fuels and cement from company regulatory filings and reports to shareholders. These raw data are converted to annual production and thus are then comparable to estimates of global emissions typically reported at annual frequency.

The objective of the CAI's data collection efforts is to quantify and trace historic and cumulative emissions of greenhouse gas to carbon-producing entities. In order to do so, physical quantities of fossil fuels produced and marketed worldwide are converted to emissions for each fuel type using conversion factors following international standards and conventions in IPCC reports. For example, Royal Dutch Shell's 'net equity' production of oil in 2017 was $666 \mathrm{Mb}$ (million barrels), which corresponds to 247 million tons of carbon dioxide (MtCO2) based on the conversion factor of $0.3714 \mathrm{MtCO} 2 / \mathrm{Mb}$. Its 'gas available for sale' in that same year was 3,894 billion cubic feet (Bcf), which translates to 208 MtCO2 after multiplying by the conversion factor $0.05343 \mathrm{MtCO} 2 / \mathrm{Bcf}$. Combined, emissions from oil and gas attributed to Shell in 2017 were $456 \mathrm{MtCO} 2$.

Emissions can be categorized into three scopes. Scope 1 emissions are a direct result of firms' activities, for example planes flown by an airline. Scope 2 emissions are indirect results of companies' operations. Continuing with the example of airlines, this would include emissions resulting from the procurement and use of electricity to maintain aircraft hangars. Scope 3 emissions result from customers using a company's products as intended, or from sources related to the company's operations, but not owned or directly controlled by the firm itself, for example, end-of-life disposal, or employee commuting. In the case of large emitters such as fossil fuel producers, it is essential to consider Scope 3 emissions. The data we use on large emitters covers 
Scopes 1 and 3 as defined by the World Resource Institute (WRI). Previous work using firm-level emissions has focused on Scope 1 and 2. In contrast, in our analysis Scope 2 is excluded. This prevents double-counting, as the goal is to trace emissions to the producing entity at-source and not to the end-user, even when that end-user is another major emitter.

Coverage in the dataset is comprehensive: it includes firms with emissions above 8 million tons of carbon (MtC) per year and reporting on a consolidated basis. Historical mergers and acquisitions are accounted for by back-filling the series pro-forma for the combined entity. The full dataset includes 96 firms, of which 67 are oil and gas producers, 25 coal producers, and 4 cement manufacturers. 64 of the 96 firms are investor-owned, while the remaining 32 firms are state-owned enterprises.11 We are able to obtain ESG data, discussed below, for 61 of these 64 investor-owned firms. Notably, despite their small number, the firms in the dataset account for about 70 percent of cumulative greenhouse gas emissions since 1850, and 86 percent of the cumulative flow of carbon dioxide emissions since 2002. In principle, well-executed ESG investing could incentivize these upstream firms to collectively slow production, likely raising the cost of operating in production chains reliant on carbon emissions, curtailing emissions 12

\subsection{ESG data}

ESG considerations are a set of criteria that investors can use in evaluating investment opportunities to make sustainable investment decisions. ESG scoring provides evaluations of company performance in various dimensions such as environmental and community impact, waste control, and labor and governance practices. In recent years, sustainable investment has become increasingly popular, especially with the rise in public attention to the risks posed by climate change (Giglio et al. 2020). Krueger et al. (2020) report that one third of large institutional investors surveyed have already integrated ESG indicators into their investment processes.

\footnotetext{
${ }^{11} \mathrm{~A}$ few nations where there is record of fuel production carried out by the state are also included as entities in the data.

${ }^{12}$ While examining the link between ESG scores and emissions for firms that are located more downstream in production chains reliant on carbon emissions would also be interesting, lack of enforced disclosure makes studying a broad swathe of firms more challenging.
} 
While some investors collect data on ESG issues themselves, many incorporate ratings from third-party sources in their investment decisions. There are many reputable private providers of these ratings, including Refinitiv (Thomson Reuters), from which we source our ESG data. We collect the overall ESG score, as well as scores for its three pillars-Environmental (E), Social $(\mathrm{S})$, and Governance $(\mathrm{G})$ considerations - and their components, with each score ranging from 1 to 100. The Environmental pillar provides various measures of how companies' operations impact the environment. For example, a company may receive a higher environmental score if it has set a target to lower emissions, or if it is efficient in resource use, and waste management. The Social pillar captures a company's relationship with its employees, suppliers, and the communities in which it operates. Specific inputs include whether the company offers flexible work hours or day care services to its employees. Finally, the Governance pillar evaluates the effectiveness of company management and management practices. This pillar consists of three components: management, corporate social responsibility, and shareholders. Within management are issues such as gender representation on the executive board, and shareholders rights. The E and S components are constructed to provide within-industry comparisons. Governance scores are comparable across industries within firms with the same country of incorporation.

Before we move on to the panel dataset created by merging firm-level emissions data with ESG scores, it is worth noting that ESG measurement continues to evolve. There is no industry standard or regulatory guidance on how ESG scores should be constructed, hence the scores could diverge considerably depending on the source. Indeed, several researchers have found disagreements across providers of ESG scores (Gibson et al. 2021, Berg et al. 2020, International Monetary Fund 2019, Christensen et al. 2019)13 Rather than indicating the relative quality of assessments, this finding suggests that raters can disagree on the extent of ESG definition as well as how various aspects of this definition should be measured. Berg et al. (2020) show that disagreements can be attributed to both different choices of ESG attributes to include and

\footnotetext{
${ }^{13}$ ? shows that high ESG scores can reflect higher emissions across providers, although this study relies on voluntary reporting of emissions, excludes Scope 3 emissions, and focuses on levels of emissions rather than changes.
} 
different assessments of performance in these areas. Interestingly, Gibson et al. (2021) show that disagreements are particularly acute for the governance pillar rather than the environment pillar. As discussed earlier, however, data is not a major constraint for the important set of firms we focus on when it comes to emissions - direct estimates of emissions are available at the firm level.

\subsection{Combined panel}

Our panel dataset combines emissions and ESG scores with firm-level financial data and country controls. We focus on private companies, as ESG scores are not available for state-owned enterprises, and restrict our analysis to the years 2002 to 2017: our data on ESG scores begins in 2002, and 2017 is the most recent year for which emissions for these large emitters are available ${ }^{14}$ Exchange rates from the IMF's International Financial Statistics are used to convert all firm financial data into U.S. dollars. We construct a panel covering 61 investor-owned firms, headquartered in 23 countries, that between 2002 and 2017 represented 29.4 percent of global cumulative emissions. Of the 64 investor-owned firms for which we have data on emissions, we drop three for which ESG scores are not available. For our baseline analysis, we focus on a subset of 52 firms for which we have at least 10 years of data, and that represented 27 percent of global cumulative emissions.

\section{$3 \quad$ Empirical Results}

Before examining whether ESG scores are related to emissions growth across large emitters, we briefly discuss a series of possibilities for why there may be some connection. First, better ESG scores may reflect slower emissions growth to the extent that emissions, or efforts to reduce emissions, are used as inputs in constructing ESG scores. Indeed, as we discuss above, such a relationship is an important prerequisite for moves by climate-sensitive investors to invest in, or engage differently with, firms with high ESG scores to help address climate change. Second, and

\footnotetext{
${ }^{14}$ Our data on ownership by institutional investors begins in 2005.
} 
relatedly, firms with better ESG scores may be better able to slow emissions growth. Among other possibilities, they may face lower costs of capital (Oehmke \& Opp 2020) or a more sticky investor base. Third, firms with high emissions growth may be strongly motivated to engage in window dressing - making efforts to merely improve their ESG scores without slowing emissions growth - to affect perceptions of both investors and policymakers ${ }^{15}$ This final possibility implies that firms with higher emissions growth may receive higher, not lower, ESG scores. It is important to note that we examine conditional correlations between ESG scores and emissions growth. We do not interpret our results in a causal manner.

We first ask whether a negative relationship between ESG scores and the growth rate of emissions is visible in the raw cross section. In Figure 2, we show how average emissions growth relates to averages of three sustainable investment criteria that are particularly relevant for investors concerned with climate risk and firms' sustainability: overall ESG score, environmental pillar score, and governance pillar score. The overall ESG score and the score on the Governance pillar are of interest because investors use ESG scores in a variety of investment strategies (Matos 2020, International Monetary Fund 2019, Amel-Zadeh \& Serafeim 2018), often aiming to incorporate ESG considerations as a group. The three panels in the left vertical column show raw averages. We plot the growth rate of emissions for each company during the four-year period that it experienced the largest increase in its ESG scores (middle vertical column) to see if a corresponding decrease in the growth rate of emissions is observed. In the panels in the right vertical column, we instead plot the ESG scores in the four-year period that corresponds to each company's largest decrease in emissions growth rate. In the cross-section as well as in the periods with the largest improvements in ESG scores or reductions in emissions, emissions growth appears largely unrelated to any of the three sustainability scores. Appendix Figures A.2 and A.3 show that scaling emissions by either revenue or assets does not alter this impression ${ }^{16}$

\footnotetext{
${ }^{15}$ Media reports indicate that some investors view ESG-linked investing as a substitute for more stringent government regulation.

${ }^{16}$ Appendix Figure A.4 shows that there is also no systematic relationship between emissions growth and the Social component of ESG scores.
} 


\subsection{Regressions}

Next, we turn to firm-level regressions to more formally assess whether there is a negative relationship between ESG scores and emissions growth for major emitters. We employ a fixed effects model with variations of the following specification:

$$
Y_{i t}=\alpha_{i}+\alpha_{t}+\beta_{1} \text { Score }_{i t}+\gamma X_{i t}+\epsilon_{i t}
$$

$Y$ is the log difference in emissions and Score is the ESG score for firm $i$ in year $t$. We present regressions for overall ESG score, each of the three pillars, as well as the main components of each pillar. We include firm fixed effects $\left(\alpha_{i}\right)$ and year fixed effects $\left(\alpha_{t}\right)$ to absorb any firm and year invariant factors. In an alternative specification, we use country instead of firm fixed effects ${ }^{17} X_{i t}$ is a vector of firm and country controls, including firm size as measured by the lag of log total assets, lagged log revenue, lagged leverage measured as debt-to-asset ratio, lagged percent change in fixed asset growth, current and lagged values of real GDP growth, inflation, and unemployment rates. ${ }^{18}$ We include both assets and revenue as controls as these firms have different cost structures and production processes. Standard errors are double clustered at the firm and year level ${ }^{19}$ Log differences are multiplied by 100. ESG scores are standardized to have unit variance. Coefficients can therefore be read as the percentage point difference in emissions growth associated with a one standard deviation move in ESG scores.

We begin with regressions based on the overall ESG score (Panel A of Table 1). In a specification with only year fixed effects, we do find a negative and statistically significant coefficient on the overall ESG score (column 1). A one standard deviation improvement in the overall ESG score is associated with a 1.1 percentage point reduction in emissions growth. However, we do not find a statistically significant relationship between ESG scores and the growth rate of emissions

\footnotetext{
${ }^{17}$ This set of fixed effects captures some elements of differences in regulation across the firms in our panel. However, we do not aim to strip out all regulatory differences. To be useful for investors that allocate investments across jurisdictions, ESG scores should capture differences in emissions driven by regulation. Examining the role of differences across countries in more detail is an interesting area for future research.

${ }^{18} \mathrm{We}$ are unable to include country-year fixed effects as the average number of firms per country is low.

${ }^{19}$ The results are similar if we cluster only at the firm level.
} 
in specifications saturated with fixed effects (columns 2 and 3). This suggests at best a weak link between ESG and emissions growth. The loss of statistical significance when either firm or country fixed effects are included points to an important role played by unobservable country and firm characteristics. When these characteristics are not controlled for, the ESG score picks up their impact on emissions growth. Specifications with firm fixed effects are important - firms that slow emissions growth do not appear to be rewarded by better ESG scores and firms with better ESG scores do not seem to reduce emissions. Specifications with firm fixed effects also help capture firm-specific differences in the extent to which reducing emissions is challenging.

Next, we examine whether greater institutional ownership - often thought to improve corporate governance, particularly when institutions' holdings are concentrated in large blocks, and when institutions have board or management representation-affects the connection between ESG scores and emissions growth 20 Starting with a specification with only year fixed effects, Panel B of Table 1 shows that institutional ownership is greater for large emitters with faster growing emissions. This finding suggests that growing attention to ESG considerations from institutional investors could help improve ESG scoring over time. However, the negative link between ESG scores and emissions growth is concentrated in firms with higher institutional ownership. While the sign of the coefficient for the interaction between institutional ownership and ESG scores remains with country or firm fixed effects, the coefficient is no longer statistically significant (columns 2 and 3 of Panel B of Table 1).

Interestingly, the connection between ESG scores and emissions growth is even weaker for larger firms in our panel (Appendix Table A.1). Even within the set of large emitters, larger emitters may be better able to manage ESG scores without changing emissions. Indeed, Appendix Table A.2 suggests that this size effect is related to the treatment of environmental innovation. Larger firms may be more effective at managing ESG scores by highlighting innovation initia-

\footnotetext{
${ }^{20} \mathrm{~A}$ large theoretical literature on concentrated ownership and monitoring identifies two main channels through which institutional investors can influence corporate governance: voice (activist intervention) and exit (Edmans 2014). Empirical evidence tends to be mixed, highlighting differences across institutional investor types, the role of tax and securities laws, and other practical considerations. See Brav, Jiang, Partnoy \& Thomas (2008), Schmidt \& Fahlenbrach (2017), and the references therein.
} 
tives without changing emissions. In line with this interpretation, Appendix Table A.3 shows that declared recognition of risks associated with climate change and reported environmental investments and partnerships substantially lift overall ESG and Environment pillar scores.

We move from overall ESG scores to ESG pillars and their components in Table 2, Panel A reports regressions using the Environment pillar and its components, including Emissions. Panel B reports regressions using the Governance pillar and its components. Table 2 presents specifications that include firm fixed effects. Strikingly, the Environment pillar and its components (including Emissions) are essentially unrelated to emissions growth at the firm level: coefficients are small or positive and not statistically significant (Panel A) ${ }^{21}$ Positive coefficients may reflect stronger efforts by firms with growing emissions to improve their ratings without slowing emissions growth. To the extent that there is a weak negative link between overall ESG scores and emissions growth, it seems to be driven by the Governance pillar (Panel B). Although statistical significance is marginal, a one standard deviation within-firm improvement in the Governance pillar score or the management component is associated with a $0.7-0.8$ percentage point reduction in emissions growth.

Our results are not driven by the choice of timing in our baseline specifications. Our baseline regression specifications focus on the connection between emissions growth and ESG scores in the same year. Appendix Table A.5 shows that the results remain similar if we look at emissions in subsequent or prior two years. Moreover, Figure 2 and Appendix Figures A.2 and A.3 show no apparent connection between ESG scores and emissions growth in the four year period with the largest within-firm increases in either of these.

ESG scores do not reflect differences in the level of emissions better than emissions growth for large emitters. Our baseline specifications examine the link between ESG scores and emissions growth. We do not find a strong link between either ESG scores overall or on any of the pillars and the level of emissions (Appendix Table A.6. Similarly, Appendix Figure A.5 shows little evidence of a link between ESG scores and emissions either in the cross section or in periods

\footnotetext{
${ }^{21}$ We find a similar lack of connection using the Environment pillar orthogonalized with respect to other pillars (Appendix Table A.4.
} 
when ESG scores strongly improve.

Our conclusion that we find at best a weak connection between ESG scores and emissions growth does not depend on other details of our methodological approach. Appendix Table A.7 shows regression results for the broadest set of firms we can use, not just those for which we have at least 10 years of data. Again, when relying on within-firm variation we are unable to find a statistically significant relationship between ESG scores and emissions growth 22 Appendix Tables A.9 A.14 show results for growth in emissions scaled by either assets or revenue and for the Social pillar and its components. The results are broadly unchanged or somewhat weaker. Notably, there is no statistically significant connection between overall ESG scores and emissions intensity even in specifications with only year fixed effects and no firm or country fixed effects (Appendix Table A.9). There is also no statistically significant relationship between the Governance Pillar (or the management component) and emissions scaled by revenue (Appendix Table A.10, Panel B) or emissions scaled by assets (Appendix Table A.11, Panel B).

\section{Magnitudes}

In this paper we are concerned with the question of whether private initiatives can help curtail global emissions in a meaningful way. As ESG-linked investing continues to grow rapidly, investor-owned firms, including the sample of major emitters we focus on, are likely to have incentives to improve their ESG scores to tap this source of finance. Would it be reasonable to interpret a large collective improvement in ESG scores for these emitters as a signal of real progress with addressing climate change? To answer this question, we take our largest estimated coefficient (the specification with year fixed effects but no firm or country fixed effects in Panel A of Table 1) at face value, and ask how this magnitude compares to the scale of the problem. Although we are unable to find a robust relationship between ESG scores and emissions growth, this provides a conservative sense for whether market forces like sustainable investing can help make progress with climate change.

\footnotetext{
${ }^{22}$ The results remain similar if we do not winsorize any variables (Appendix Table A.8).
} 
The scientific consensus on how to tackle climate change and the rise in global temperature is that greenhouse gas (GHG) concentrations in the atmosphere must be stabilized. This stabilization requires large reductions in the flow of global carbon dioxide emissions. In particular, net carbon dioxide emissions must be brought to or below zero. To help policymakers assess the scale of action necessary, the IPCC (2018a) reports carbon 'budgets' tied to a variety of specific climate objectives. For each objective - say to limit warming to under 1.5 degrees Celsius with a 66 percent probability - the associated carbon budget is the largest amount of carbon dioxide emissions that could be released into the atmosphere while still meeting the objective. The growth rate of global emissions is then used to estimate the remaining years before each budget is exhausted.

We use this 'remaining years' framework to investigate how many extra years an improvement in ESG scores (and the associated hypothetical reduction in the growth rate of emissions) would add before a given carbon budget would be exhausted. We do this by first allocating a carbon budget for the 52 firms in our panel in proportion to their share of global carbon emissions in 2017. We then estimate their future carbon dioxide emissions based on their average growth rate over the sample period. Finally, we calculate their cumulative emissions and the difference between when they would run out of their budget under the status quo versus under a scenario with slower emissions growth.

Unfortunately, the weak link between ESG scores and emissions growth means that even reductions in emissions growth corresponding to large improvements in ESG scores would do little to help with climate change. Table 3 summarizes the results of our scenario analysis. With business as usual, less than 14 years are left before the odds of containing global warming to under 1.5 degrees Celsius would be worse than even. The reduction in emissions growth associated with a two standard deviation improvement in ESG scores would buy only an additional two years before this objective would be out of reach. Table 3 shows that the number of years gained is similarly small relative to the baseline across a range of different climate objectives. Put differently, even if the remarkable rise of sustainable investing did incentivize large emitters 
to significantly improve their ESG scores, this would not necessarily translate into meaningful momentum in dealing with climate change.

\section{Conclusion}

ESG investing has attracted much attention in recent years, particularly in the context of climate change. By guiding climate-conscious investors and shareholders to make sustainable investment decisions, greater attention to ESG considerations could in principle lead to an equilibrium where firms strive to improve their ESG scores and, in the process, bring down emissions. An important prerequisite for sustainable investing linked to ESG scores to have this salutary effect is that firms that reduce their contributions to climate change need to be rewarded with better ESG scores.

We use data on a small but important set of firms that are among the largest emitters worldwide to explore the relation between ESG scores and emissions growth. Our results suggest a weak relationship between ESG scores and growth rate of emissions, if any. Environmentally-conscious investors, shareholders, and policymakers should note that high ESG scores are not necessarily related to companies' actual carbon footprints. Our findings suggest that there is limited scope for sustainable investing strategies conditioned solely on ESG indicators to meaningfully help mitigate climate change by shifting production incentives for large emitters. Central banks looking to manage the climate footprint of their interventions should also be wary of over-reliance on ESG indicators. 


\section{References}

Amel-Zadeh, A. \& Serafeim, G. (2018), 'Why and how investors use esg information: Evidence from a global survey', Financial Analysts Journal 74(3), 87-103.

Berg, F., Koelbel, J. F. \& Rigobon, R. (2020), 'Aggregate confusion: the divergence of esg ratings'.

Berle, A. A. (1930), 'Corporate powers as powers in trust', Harv. L. Rev. 44, 1049.

Bolton, P. \& Kacperczyk, M. (2020a), 'Global pricing of carbon-transition risk'.

Bolton, P. \& Kacperczyk, M. (2020b), 'Signaling through carbon disclosure'.

Brav, A., Jiang, W., Partnoy, F. \& Thomas, R. (2008), 'Hedge fund activism, corporate governance, and firm performance', The Journal of Finance 63(4), 1729-1775.

Broccardo, E., Hart, O. \& Zingales, L. (2020), Exit vs. voice, Working Paper w27710, NBER.

Christensen, D., Serafeim, G. \& Sikochi, A. (2019), 'Why is corporate virtue in the eye of the beholder? the case of esg ratings'.

Cohen, L., Gurun, U. G. \& Nguyen, Q. H. (2020), The esg-innovation disconnect: Evidence from green patenting, Working Paper w27990, NBER.

Cornell, B. \& Damodaran, A. (2020), 'Valuing esg: Doing good or sounding good?'.

Edmans, A. (2014), 'Blockholders and corporate governance', Annual Review Financial Economics 6(1), 23-50.

Ehlers, T., Mojon, B., Packer, F. \& da Silva, L. A. P. (2020), 'Green bonds and carbon emissions: Exploring the case for a rating system at the firm level'.

Friedman, M. (1970), 'The social responsibility of business is to increase its profits', New York Times.

Gibson, R., Glossner, S., Krueger, P., Matos, P. \& Steffen, T. (2020), 'Responsible institutional investing around the world'.

Gibson, R., Krueger, P. \& Mitali, S. F. (2020), 'The sustainability footprint of institutional investors: Esg driven price pressure and performance'.

Gibson, R., Krueger, P. \& Schmidt, P. S. (2021), Esg rating disagreement and stock returns, Research Paper Series No 19-67, Swiss Finance Institute.

Giglio, S., Kelly, B. T. \& Stroebel, J. (2020), Climate finance, Working Paper w28226, NBER.

Gillingham, K. \& Stock, J. H. (2018), 'The cost of reducing greenhouse gas emissions', Journal of Economic Perspectives 32(4), 53-72.

Green, D. \& Roth, B. N. (2021), 'The allocation of socially responsible capital'.

Hart, O. \& Zingales, L. (2017), 'Companies should maximize shareholder welfare not market value', Journal of Law, Finance, and Accounting 2(2), 247-274.

Heede, R. (2014a), Carbon majors: Accounting for carbon and methane emissions 1854-2010, Methods \& results report, Climate Mitigation Services. 
Heede, R. (2014b), 'Tracing anthropogenic carbon dioxide and methane emissions to fossil fuel and cement producers, 1854-2010', Climatic Change 122(1-2), 229-241.

Hong, H., Wang, N. \& Yang, J. (2021), Welfare consequences of sustainable finance, Working Paper w28595, NBER.

Ilhan, E., Sautner, Z. \& Vilkov, G. (2021), 'Carbon tail risk', The Review of Financial Studies 34(3), 1540-1571.

Intergovernmental Panel on Climate Change (IPCC) (2014), Summary for policymakers, in Field, C.B., V.R. Barros, D.J. Dokken, K.J. Mach, M.D. Mastrandrea, T.E. Bilir, M. Chatterjee, K.L. Ebi, Y.O. Estrada, R.C. Genova, B. Girma, E.S. Kissel, A.N. Levy, S. MacCracken, P.R. Mastrandrea, and L.L.White, ed., 'Climate change 2014: impacts, adaptation, and vulnerability. Part A: global and sectoral aspects. Contribution of Working Group II to the Fifth Assessment Report of the Intergovernmental Panel on Climate Change', Cambridge University Press, pp. 1-32.

International Monetary Fund (2019), Sustainable finance, Global Financial Stability Review Chapter 6, October 2019, International Monetary Fund.

International Monetary Fund (2020), Mitigating climate change-growth-and distribution-friendly strategies, World Economic Outlook Chapter 3, October 2020, International Monetary Fund.

Ioannou, I., Li, S. X. \& Serafeim, G. (2016), 'The effect of target difficulty on target completion: The case of reducing carbon emissions', The Accounting Review 91(5), 1467-1492.

IPCC (2018a), Mitigation pathways compatible with 1.5c in the context of sustainable development, in Masson-Delmotte, V., P. Zhai, H.-O. Prtner, D. Roberts, J. Skea, P.R. Shukla, A. Pirani, W. Moufouma-Okia, C. Pan, R. Pidcock, S. Connors, J.B.R. Matthews, Y. Chen, X. Zhou, M.I. Gomis, E. Lonnoy, T. Maycock, M. Tignor, and T. Waterfield, ed., 'Global Warming of 1.5C. An IPCC Special Report on the impacts of global warming of 1.5C above pre-industrial levels and related global greenhouse gas emission pathways, in the context of strengthening the global response to the threat of climate change, sustainable development, and efforts to eradicate poverty', World Meteorological Organization, pp. 93-174.

IPCC (2018b), Summary for policymakers, in Masson-Delmotte, V., P. Zhai, H.-O. Prtner, D. Roberts, J. Skea, P.R. Shukla, A. Pirani, W. Moufouma-Okia, C. Pan, R. Pidcock, S. Connors, J.B.R. Matthews, Y. Chen, X. Zhou, M.I. Gomis, E. Lonnoy, T. Maycock, M. Tignor, and T. Waterfield, ed., 'Global Warming of 1.5C. An IPCC Special Report on the impacts of global warming of $1.5 \mathrm{C}$ above pre-industrial levels and related global greenhouse gas emission pathways, in the context of strengthening the global response to the threat of climate change, sustainable development, and efforts to eradicate poverty', World Meteorological Organization, pp. 1-32.

Ivanov, I. T., Kruttli, M. S. \& Watugala, S. W. (2020), 'Banking on carbon: Corporate lending and cap-and-trade policy'.

Kneese, A. V. (1971), 'Environmental pollution: Economics and policy', The American Economic Review 61(2), 153-166.

Krueger, P., Sautner, Z. \& Starks, L. T. (2020), 'The importance of climate risks for institutional investors', The Review of Financial Studies 33(3), 1067-1111.

Lenton, T. M., Rockström, J., Gaffney, O., Rahmstorf, S., Richardson, K., Steffen, W. \& Schellnhuber, H. J. (2019), 'Climate tipping points-too risky to bet against'. 
Matos, P. (2020), Esg and responsible institutional investing around the world, Literature review, CFA Institute Research Foundation.

Naaraayanan, S. L., Sachdeva, K. \& Sharma, V. (2020), 'The real effects of environmental activist investing'.

Nordhaus, W. (2015), 'Climate clubs: Overcoming free-riding in international climate policy', American Economic Review 105(4), 1339-70.

Oehmke, M. \& Opp, M. M. (2020), A theory of socially responsible investment, Discussion Paper DP14351, CEPR.

Pahle, M., Burtraw, D., Flachsland, C., Kelsey, N., Biber, E., Meckling, J., Edenhofer, O. \& Zysman, J. (2018), 'Sequencing to ratchet up climate policy stringency', Nature Climate Change 8(10), 861-867.

Schmidt, C. \& Fahlenbrach, R. (2017), 'Do exogenous changes in passive institutional ownership affect corporate governance and firm value?', Journal of Financial Economics 124(2), 285306.

Seltzer, L., Starks, L. \& Zhu, Q. (2020), 'Climate regulatory risks and corporate bonds'.

Shive, S. A. \& Forster, M. M. (2020), 'Corporate governance and pollution externalities of public and private firms', The Review of Financial Studies 33(3), 1296-1330.

Shleifer, A. \& Vishny, R. W. (1997), 'A survey of corporate governance', The Journal of Finance $\mathbf{5 2}(2), 737-783$.

Solow, R. M. (1972), 'The economist's approach to pollution and its control', Social Science pp. $15-25$.

Starks, L. (2020), Climate risk and investors, Keynote address, 2020 FMA Virtual Conference.

Weitzman, M. L. (2009), 'On modeling and interpreting the economics of catastrophic climate change', The Review of Economics and Statistics 91(1), 1-19.

Zingales, L., Kasperkevic, J. \& Schechter, A. (2020), Milton Friedman 50 Years Later, Stigler Center. 
Figure 1: Stock and flow of global carbon emissions traced to large emitters

Notes: This figure shows the stock (Panel A) and flow (Panel B) of global carbon emissions, breaking out emissions attributable to the 52 large emitters in our baseline panel and to the remaining large emitters tracked in our firm-level emissions data. Panel B shows emitter types as shares of the flow in each year.

Panel A: Stock of global carbon emissions since 1940

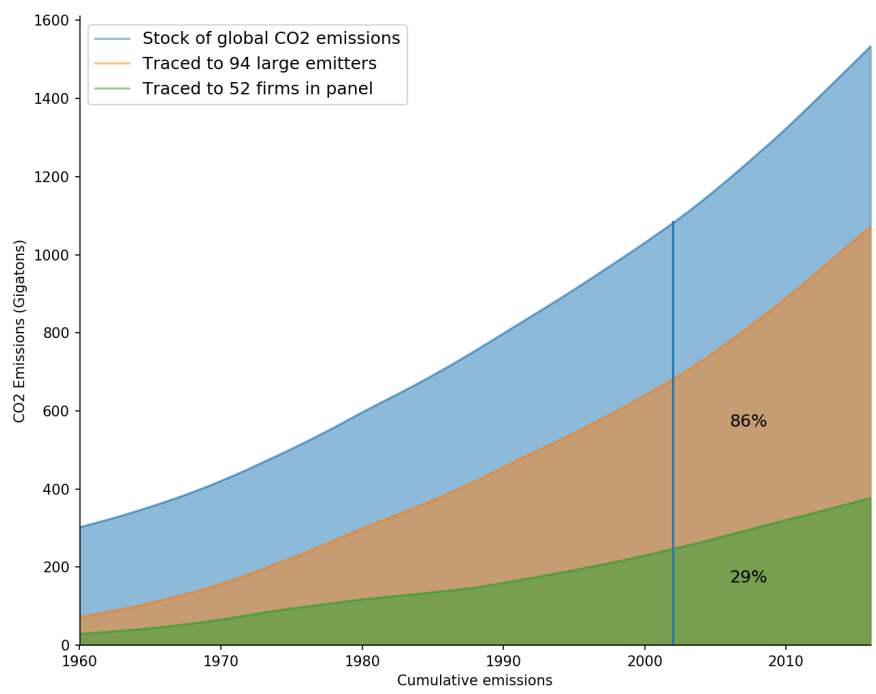

Panel B: Global carbon emissions since 2002

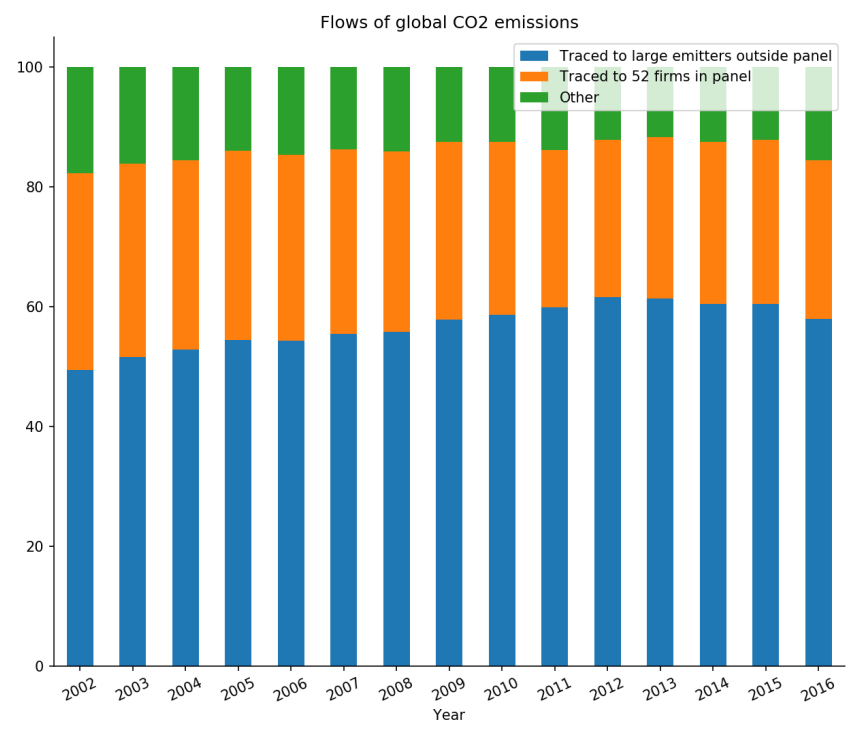


Figure 2: ESG and emissions growth in the cross section

Notes: This figure shows ESG scores and emissions growth in the cross section. The first row shows overall ESG scores. The second and third rows show scores for the Governance and Environment pillar respectively. The left column shows averages over the full sample. The middle column shows averages for the four year period with the largest increase in emissions. The right column instead shows averages in the four year period with the largest improvement in ESG scores. Bubble sizes represent the average absolute size of emissions. Shading indicates economic conditions: darker red represents slower economic growth. Outliers are trimmed.
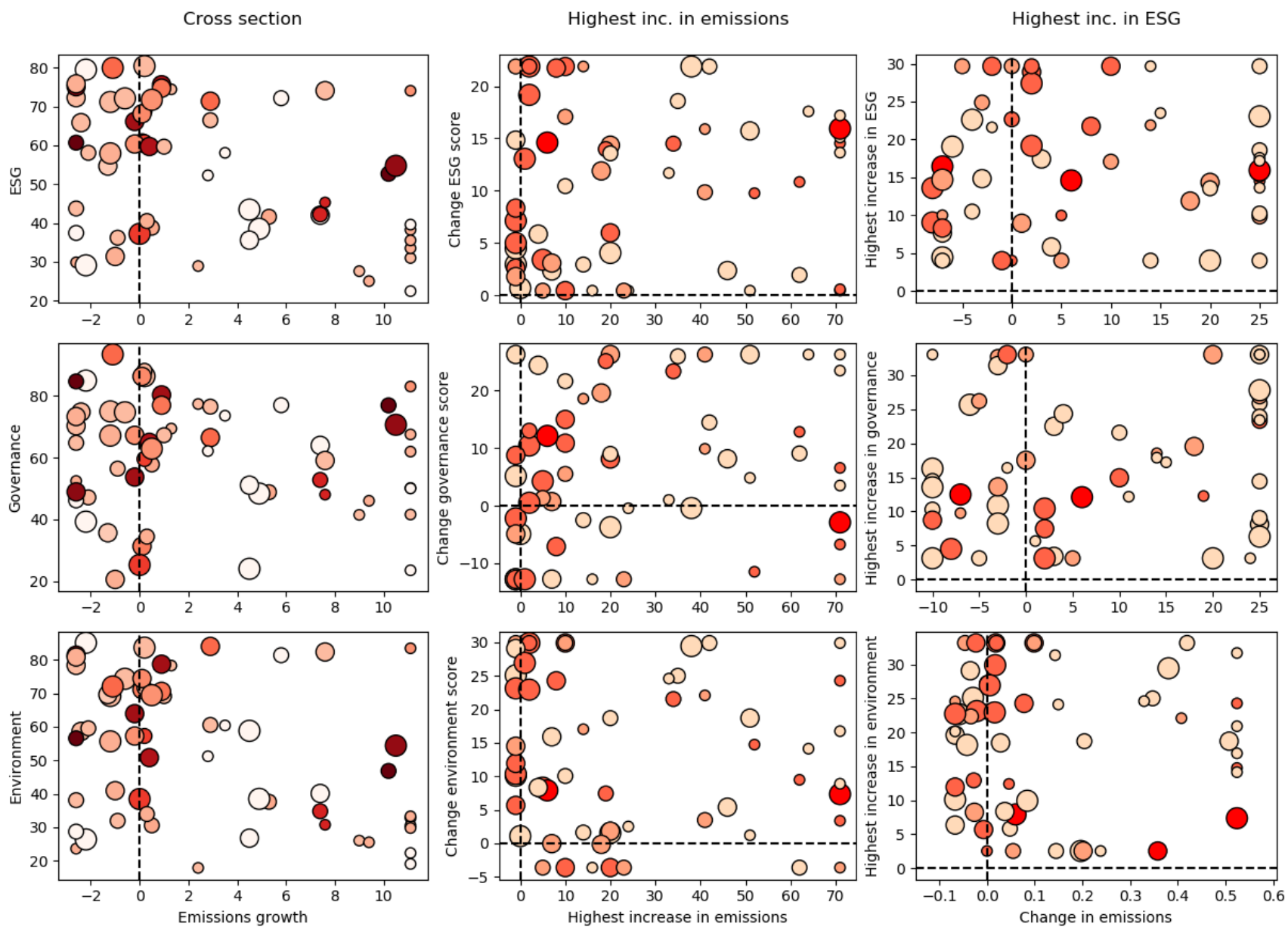
Table 1: Emissions growth, overall ESG score, and institutional ownership

Notes: This table shows regressions at the firm-year level where the dependent variable is the log change in emissions (in percentage points and winsorized at the 5th and 95th percentiles). A one unit change in the ESG score and institutional (inst) ownership corresponds to the median within-firm standard deviation. Firm controls include lagged log assets, lagged log revenue, lagged percent change in leverage, and lagged fixed asset growth (all winsorized at the 5th and 95th percentiles). Country controls include current and lagged GDP growth, unemployment rate, and inflation. Firms are mapped to their countries of incorporation. Standard errors, reported in parentheses, are double-clustered at the firm and year level. ${ }^{*},{ }^{* *}$, and ${ }^{* * *}$ denote statistical significance at the 10 percent, 5 percent, and 1 percent levels, respectively.

\section{Panel A: Overall ESG score}

\begin{tabular}{lrrr}
\hline & $\Delta \ln ($ Emissions $)$ & $\Delta \ln ($ Emissions $)$ & $\Delta \ln ($ Emissions $)$ \\
\hline Overall ESG Score & $-1.1^{* *}$ & -0.5 & -0.5 \\
& $(0.39)$ & $(0.45)$ & $(0.55)$ \\
\hline Year fixed effects & $\mathrm{Y}$ & $\mathrm{Y}$ & $\mathrm{Y}$ \\
Country fixed effects & $\mathrm{N}$ & $\mathrm{Y}$ & $\mathrm{N}$ \\
Firm fixed effects & $\mathrm{N}$ & $\mathrm{N}$ & $\mathrm{Y}$ \\
Firm controls & $\mathrm{Y}$ & $\mathrm{Y}$ & $\mathrm{Y}$ \\
Country controls & $\mathrm{Y}$ & 0.19 & 0.34 \\
$R^{2}($ within $)$ & 0.13 & 683 & 683 \\
Firm-years & 683 & 52 & 52 \\
Firms & 52 & 20 & 20 \\
Countries & 20 & & \\
\hline
\end{tabular}

Panel B: Overall ESG score and institutional ownership

\begin{tabular}{lrrr}
\hline & $\Delta \ln ($ Emissions $)$ & $\Delta \ln ($ Emissions $)$ & $\Delta \ln ($ Emissions $)$ \\
\hline Overall ESG Score & 0.1 & 0.5 & -0.3 \\
& $(0.51)$ & $(0.91)$ & $(0.80)$ \\
Inst ownership & $0.9^{* * *}$ & $0.6^{*}$ & 0.1 \\
& $(0.26)$ & $(0.34)$ & $(0.45)$ \\
Overall ESG Score $\times$ Inst ownership & $-0.2^{* * *}$ & -0.1 & -0.0 \\
& $(0.04)$ & $(0.07)$ & $(0.06)$ \\
\hline Year fixed effects & $\mathrm{Y}$ & $\mathrm{Y}$ & $\mathrm{Y}$ \\
Country fixed effects & $\mathrm{N}$ & $\mathrm{Y}$ & $\mathrm{Y}$ \\
Firm fixed effects & $\mathrm{N}$ & $\mathrm{Y}$ & $\mathrm{Y}$ \\
Firm controls & $\mathrm{Y}$ & $\mathrm{Y}$ & 0.35 \\
Country controls & $\mathrm{Y}$ & 0.24 & 567 \\
$R^{2}($ within $)$ & 0.18 & 567 & 50 \\
Firm-years & 567 & 50 & 20 \\
Firms & 50 & 20 & \\
Countries & 20 & & \\
\hline
\end{tabular}


Table 2: Emissions growth and Environment and Governance pillars

Notes: This table shows regressions at the firm-year level where the dependent variable is the log change in emissions (in percentage points and winsorized at the 5th and 95th percentiles). One unit change in the score on the Environment or Governance pillars or their components corresponds to the median within-firm standard deviation. Firm controls include lagged log assets, lagged log revenue, lagged percent change in leverage, and lagged fixed asset growth (all winsorized at the 5th and 95th percentiles). Country controls include current and lagged GDP growth, unemployment rate, and inflation. Firms are mapped to their countries of incorporation. Standard errors, reported in parentheses, are double-clustered at the firm and year level.*, ${ }^{* *}$, and ${ }^{* * *}$ denote statistical significance at the 10 percent, 5 percent, and 1 percent levels, respectively.

Panel A: Environment pillar and its components

\begin{tabular}{|c|c|c|c|c|}
\hline & $\Delta \ln ($ Emissions $)$ & $\Delta \ln ($ Emissions $)$ & $\Delta \ln ($ Emissions $)$ & $\Delta \ln ($ Emissions $)$ \\
\hline Environment & $\begin{array}{r}0.3 \\
(0.59)\end{array}$ & & & \\
\hline Emissions & & $\begin{array}{r}0.5 \\
(0.54)\end{array}$ & & \\
\hline Resource Use & & & $\begin{array}{r}-0.1 \\
(0.51)\end{array}$ & \\
\hline Env. Innovation & & & & $\begin{array}{r}0.0 \\
(0.31)\end{array}$ \\
\hline Year fixed effects & $\mathrm{Y}$ & $\mathrm{Y}$ & $\mathrm{Y}$ & $\mathrm{Y}$ \\
\hline Firm fixed effects & $\mathrm{Y}$ & $\mathrm{Y}$ & $\mathrm{Y}$ & $\mathrm{Y}$ \\
\hline Firm controls & $\mathrm{Y}$ & Y & Y & $\mathrm{Y}$ \\
\hline Country controls & $\mathrm{Y}$ & Y & Y & $\mathrm{Y}$ \\
\hline$R^{2}$ (within) & 0.34 & 0.34 & 0.34 & 0.34 \\
\hline Firm-years & 683 & 683 & 683 & 683 \\
\hline Firms & 52 & 52 & 52 & 52 \\
\hline Countries & 20 & 20 & 20 & 20 \\
\hline
\end{tabular}

Panel B: Government pillar and its components

\begin{tabular}{|c|c|c|c|c|}
\hline & $\Delta \ln ($ Emissions $)$ & $\Delta \ln ($ Emissions $)$ & $\Delta \ln ($ Emissions $)$ & $\Delta \ln ($ Emissions $)$ \\
\hline Governance & $\begin{array}{c}-0.8^{*} \\
(0.44)\end{array}$ & & & \\
\hline Management & & $\begin{array}{c}-0.7^{*} \\
(0.39)\end{array}$ & & \\
\hline CSR Strategy & & & $\begin{array}{r}-0.5 \\
(0.37)\end{array}$ & \\
\hline Shareholders & & & & $\begin{array}{r}-0.2 \\
(0.45)\end{array}$ \\
\hline Year fixed effects & $\mathrm{Y}$ & $\mathrm{Y}$ & $\mathrm{Y}$ & $\mathrm{Y}$ \\
\hline Firm fixed effects & $\mathrm{Y}$ & Y & $\mathrm{Y}$ & $\mathrm{Y}$ \\
\hline Firm controls & $\mathrm{Y}$ & $\mathrm{Y}$ & $\mathrm{Y}$ & $\mathrm{Y}$ \\
\hline Country controls & $\mathrm{Y}$ & Y & $\mathrm{Y}$ & $\mathrm{Y}$ \\
\hline$R^{2}$ (within) & 0.35 & 0.35 & 0.34 & 0.34 \\
\hline Firm-years & 683 & 683 & 683 & 683 \\
\hline Firms & 52 & 52 & 52 & 52 \\
\hline Countries & 20 & 20 & 20 & 20 \\
\hline
\end{tabular}


Table 3: Additional years until climate budgets exhausted

Notes: This table uses carbon budgets prepared by the IPCC (2018a) that correspond to a range of objectives for containing the risk of warming. Budgets are allocated to the 52 firms in the sample for Table 1 in proportion to their share of global carbon emissions in 2017. The first column reports years left before the budget is exhausted (and achieving the climate target requires subsequent carbon neutrality) in a business-as-usual scenario (using the average growth rate for firms in the sample from 2002-2017, 3.85 percent). The second and third columns report the number of additional years before budgets are exhausted if ESG improves for all firms in the sample by multiples of the median within-firm improvement observed from 2002-2017. A one standard-deviation improvement in ESG is assumed in this table to reduce emissions growth by 1.1 percent, based on the first specification in Panel A of Table 1

\begin{tabular}{|c|c|c|c|}
\hline \multirow[b]{2}{*}{ Climate objective scenarios } & Years left & \multicolumn{2}{|c|}{ Years gained by ESG improvement } \\
\hline & Business as usual & $\mathrm{ESG}+1 \mathrm{SD}$ & $\mathrm{ESG}+2 \mathrm{SD}$ \\
\hline \multicolumn{4}{|c|}{ Probability of warming under $1.5^{\circ} \mathrm{C}$} \\
\hline 66 percent & 10.6 & 0.6 & 1.3 \\
\hline 50 percent & 13.8 & 0.9 & 2.1 \\
\hline 33 percent & 18.2 & 1.6 & 3.6 \\
\hline \multicolumn{4}{|c|}{ Probability of warming under $2^{\circ} \mathrm{C}$} \\
\hline 66 percent & 22.9 & 2.4 & 5.7 \\
\hline 50 percent & 26.9 & 3.3 & 7.7 \\
\hline
\end{tabular}




\section{Appendix}

\section{Limits to Private Climate Change Mitigation}




\section{A Additional figures and tables}

Figure A.1: ESG score for large emitters in panel vs SEP500 companies

Notes: This figure shows how ESG scores for large emitters compare to ESG scores for S\&P500 companies (labeled as 'other companies'). The top left panel shows the average overall score in the time series. The top right panel shows the score on the Environment pillar in the time series. The bottom left panel shows the score on the Governance pillar in the time series. The bottom right panel shows the distribution of the overall score in 2004 (the box and whisker plot shows the 90th percentile, 75th percentile, median, 25th percentile, and 10th percentile).
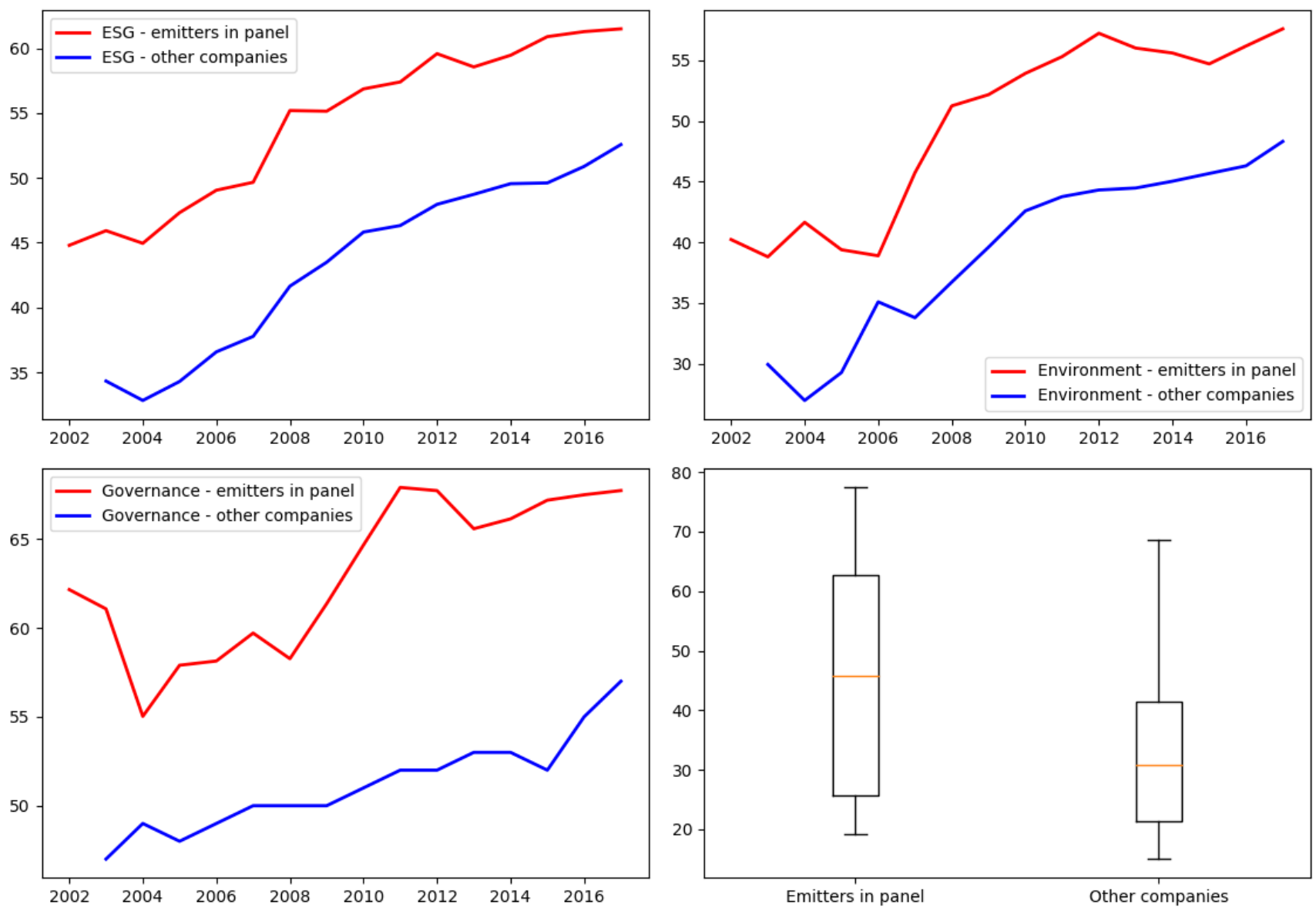
Figure A.2: ESG and growth in emissions scaled by revenue in the cross section Notes: This figure repeats Figure 2 but shows growth in emissions scaled by revenue instead.
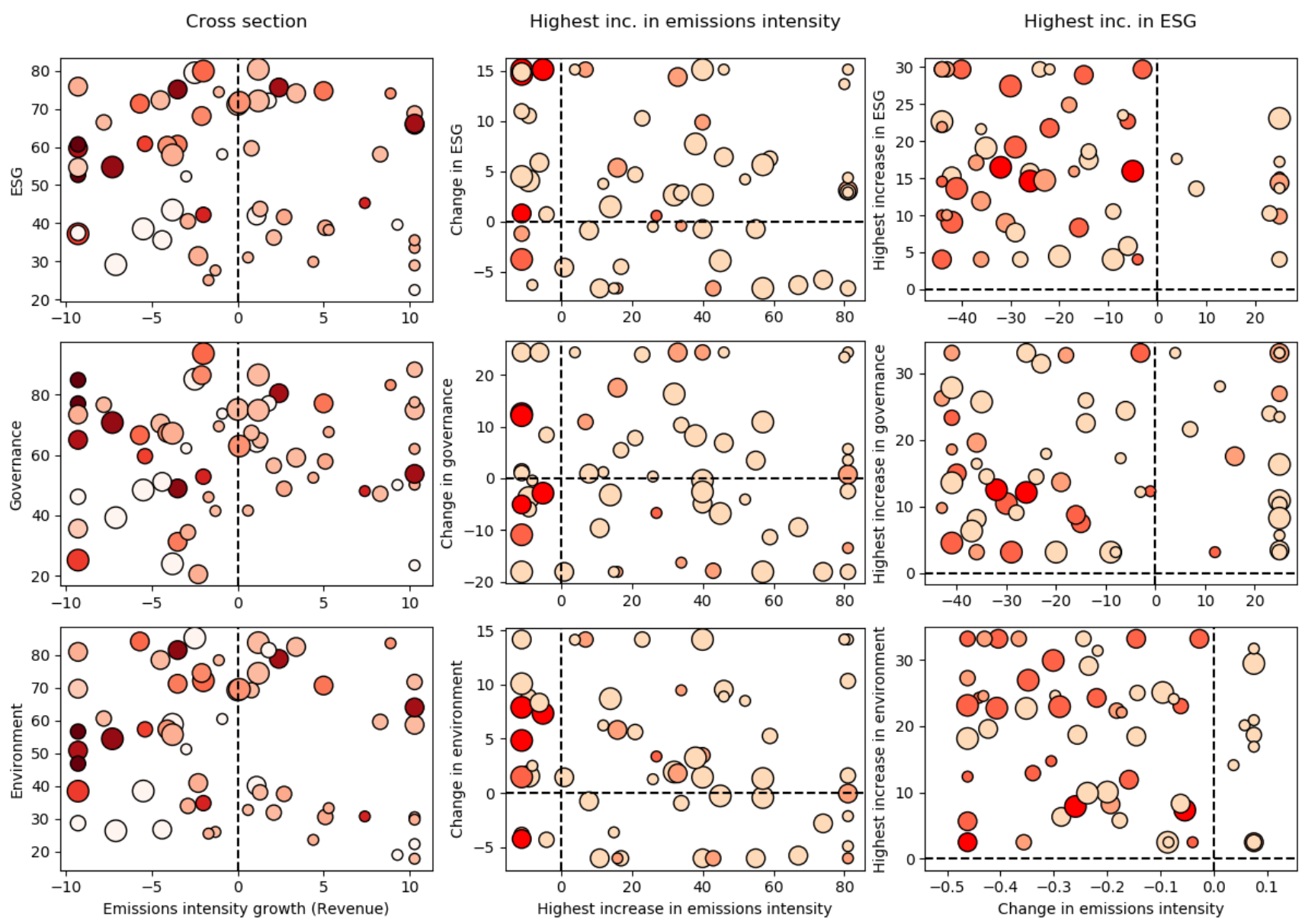
Figure A.3: ESG and growth in emissions scaled by assets in the cross section Notes: This figure repeats Figure 2 but shows growth in emissions scaled by assets instead.

Cross section
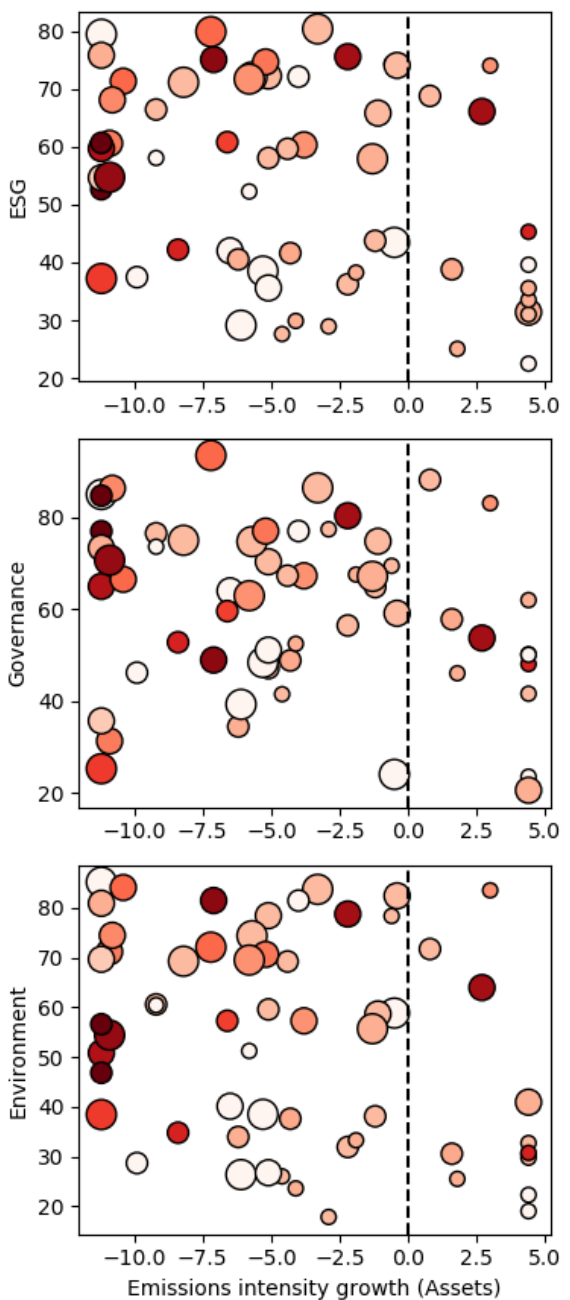

Highest inc. in emissions
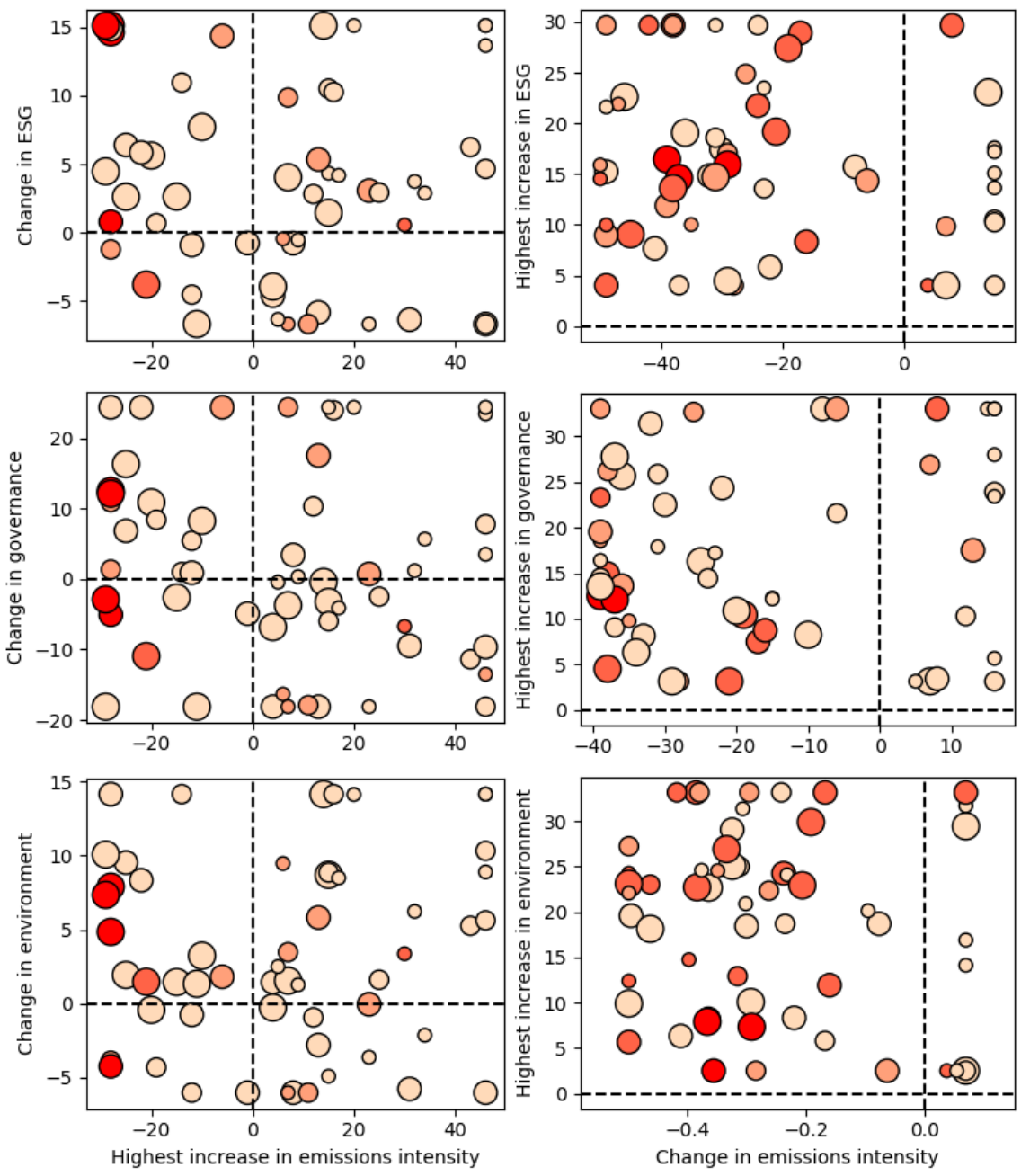
Figure A.4: Social pillar and emissions growth in the cross section

Notes: This figure shows the Social pillar and growth in emissions and emissions intensity in the cross section. The three rows show emissions growth and growth in emissions scaled by revenue and assets respectively. The left column shows averages over the full sample. The middle column shows averages in the four year period with the largest improvement in ESG scores. The right column instead shows averages for the four year period with the largest increase in emissions. Bubble sizes represent the emissions. Shading indicates economic conditions (darker red represents slower economic growth). Outliers are trimmed.
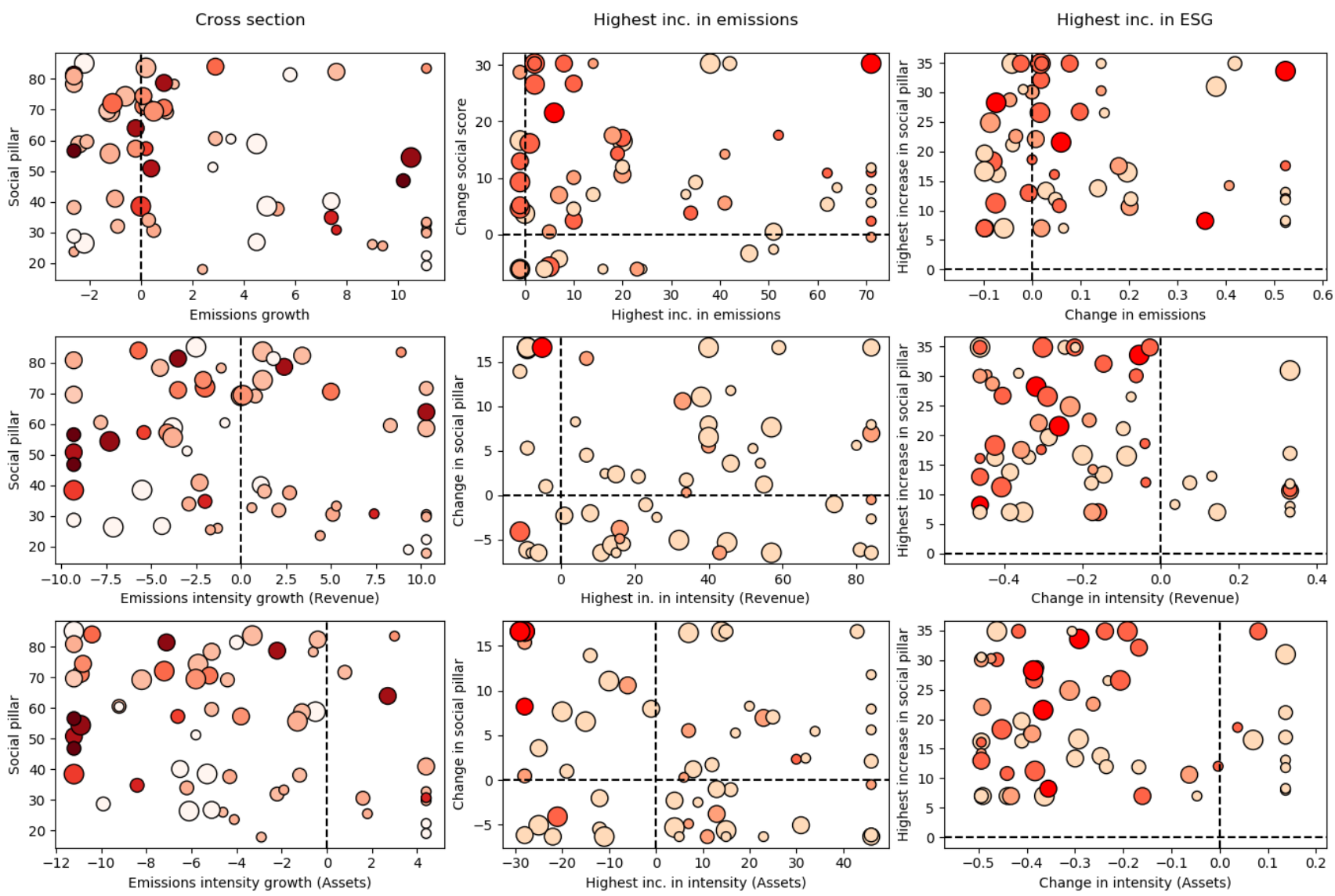
Figure A.5: ESG and the level of emissions in the cross section

Notes: This figure repeats panels in the first two columns of Figure 2, but shows the level of emissions instead.
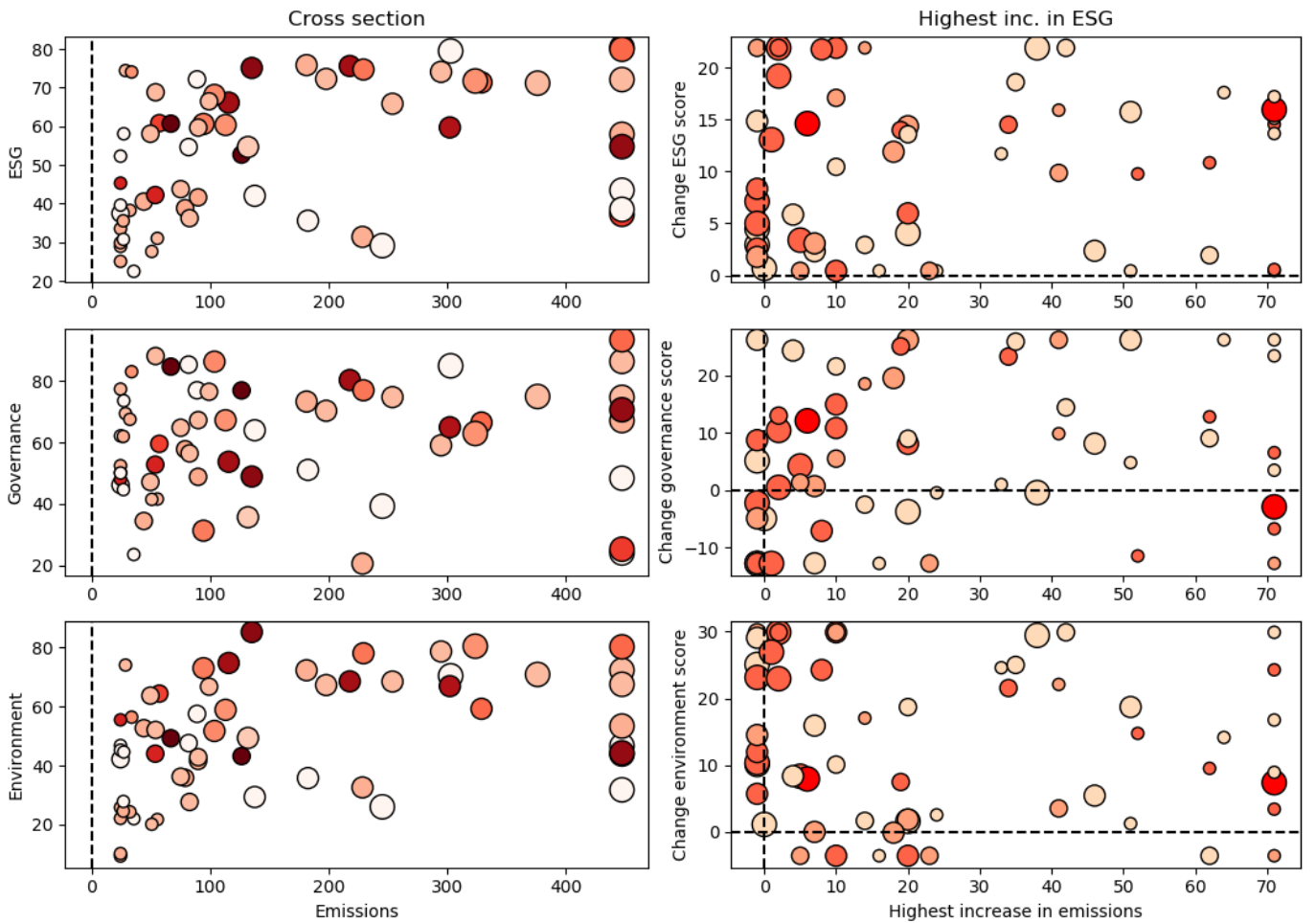
Table A.1: Emissions growth and overall ESG score conditional on firm size

Notes: This table repeats the analysis in Panel A of Table11including an interaction between the ESG score and firm size.

\begin{tabular}{lrrr}
\hline & $\Delta \ln ($ Emissions $)$ & $\Delta \ln ($ Emissions $)$ & $\Delta \ln ($ Emissions $)$ \\
\hline Overall ESG Score & $-10.4^{* *}$ & $-9.1^{*}$ & -5.0 \\
& $(3.77)$ & $(4.29)$ & $(4.59)$ \\
Log Lag Assets & -0.5 & -1.7 & -1.0 \\
& $(1.58)$ & $(1.79)$ & $(1.66)$ \\
Overall ESG Score $\times$ Log Lag Assets & $0.4^{* *}$ & $0.3^{*}$ & 0.2 \\
& $(0.14)$ & $(0.17)$ & $(0.18)$ \\
\hline Year fixed effects & $\mathrm{Y}$ & $\mathrm{Y}$ & $\mathrm{Y}$ \\
Country fixed effects & $\mathrm{N}$ & $\mathrm{Y}$ & $\mathrm{Y}$ \\
Firm fixed effects & $\mathrm{N}$ & $\mathrm{Y}$ & $\mathrm{Y}$ \\
Firm controls & $\mathrm{Y}$ & $\mathrm{Y}$ & 0.36 \\
Country controls & $\mathrm{Y}$ & 0.22 & 602 \\
$R^{2}$ (within) & 0.16 & 602 & 52 \\
Firm-years & 602 & 52 & 20 \\
Firms & 52 & 20 & \\
Countries & 20 & & \\
\hline
\end{tabular}


Table A.2: The Environment pillar conditional on firm size

Notes: This table repeats the analysis in Panel A of Table 2, including interactions between the score on the Environment pillar and its components with firm size.

\begin{tabular}{|c|c|c|c|c|}
\hline & $\Delta \ln ($ Emissions $)$ & $\Delta \ln ($ Emissions $)$ & $\Delta \ln ($ Emissions $)$ & $\Delta \ln ($ Emissions $)$ \\
\hline Environment & $\begin{array}{r}-6.6 \\
(4.68)\end{array}$ & & & \\
\hline Log Lag Assets & $\begin{array}{r}-1.3 \\
(1.91)\end{array}$ & $\begin{array}{r}-0.9 \\
(2.12)\end{array}$ & $\begin{array}{r}-1.0 \\
(1.97)\end{array}$ & $\begin{array}{r}-0.9 \\
(2.03)\end{array}$ \\
\hline Environment $\times$ Log Lag Assets & $\begin{array}{r}0.3 \\
(0.19)\end{array}$ & & & \\
\hline Emissions & & $\begin{array}{r}-0.9 \\
(3.36)\end{array}$ & & \\
\hline Emissions $\times$ Log Lag Assets & & $\begin{array}{r}0.1 \\
(0.12)\end{array}$ & & \\
\hline Resource Use & & & $\begin{array}{r}-7.1 \\
(4.63)\end{array}$ & \\
\hline Resource Use $\times$ Log Lag Assets & & & $\begin{array}{r}0.3 \\
(0.19)\end{array}$ & \\
\hline Env. Innovation & & & & $\begin{array}{l}-7.4^{*} \\
(3.54)\end{array}$ \\
\hline Env. Innovation $\times$ Log Lag Assets & & & & $\begin{array}{r}0.3^{*} \\
(0.14)\end{array}$ \\
\hline Year fixed effects & $\mathrm{Y}$ & $\mathrm{Y}$ & $\mathrm{Y}$ & $\mathrm{Y}$ \\
\hline Firm fixed effects & Y & $\mathrm{Y}$ & $\mathrm{Y}$ & $\mathrm{Y}$ \\
\hline Firm controls & $\mathrm{Y}$ & $\mathrm{Y}$ & $\mathrm{Y}$ & $\mathrm{Y}$ \\
\hline Country controls & $\mathrm{Y}$ & $\mathrm{Y}$ & $\mathrm{Y}$ & $\mathrm{Y}$ \\
\hline$R^{2}$ (within) & 0.36 & 0.36 & 0.36 & 0.36 \\
\hline Firm-years & 602 & 602 & 602 & 602 \\
\hline Firms & 52 & 52 & 52 & 52 \\
\hline Countries & 20 & 20 & 20 & 20 \\
\hline
\end{tabular}


Table A.3: ESG and Environment Scores and inputs to Environment Scores

Notes: This table shows regressions at the firm-year level where the dependent variables are either the Overall ESG Score or the score on the Environment pillar, standardized to each have unit standard deviation. The main independent variables are binary variables for specific inputs to the Environment pillar. Firm controls include lagged log assets, lagged log revenue, lagged percent change in leverage, and lagged fixed asset growth (all winsorized at the 5th and 95th percentiles). Country controls include current and lagged GDP growth, unemployment rate, and inflation. Firms are mapped to their countries of incorporation. Standard errors, reported in parentheses, are double-clustered at the firm and year level.*, ${ }^{* *}$, and ${ }^{* * *}$ denote statistical significance at the 10 percent, 5 percent, and 1 percent levels, respectively.

\begin{tabular}{lrr}
\hline & Overall ESG Score & Environment \\
\hline Attempt reduction in volatile organic compounds & $0.56^{* * *}$ & $0.72^{* * *}$ \\
& $(0.12)$ & $(0.11)$ \\
Recognize climate risks \& opportunities & $0.60^{* * *}$ & $0.52^{* * *}$ \\
& $(0.10)$ & $(0.10)$ \\
Report environmental investments & $0.41^{* * *}$ & $0.30^{* *}$ \\
& $(0.11)$ & $(0.12)$ \\
Report environmental partnerships & $0.34^{* * *}$ & $0.37^{* * *}$ \\
& $(0.11)$ & $(0.10)$ \\
\hline Year fixed effects & $\mathrm{Y}$ & $\mathrm{Y}$ \\
Firm fixed effects & $\mathrm{Y}$ & $\mathrm{Y}$ \\
Firm controls & $\mathrm{Y}$ & $\mathrm{Y}$ \\
Country controls & $\mathrm{Y}$ & $\mathrm{Y}$ \\
$R^{2}($ within $)$ & 0.89 & 0.88 \\
Firm-years & 683 & 683 \\
Firms & 52 & 52 \\
\hline
\end{tabular}


Table A.4: The Environment pillar orthogonalized with respect to other pillars

Notes: This table repeats the analysis in Panel A of Table 1, using the score on the Environment pillar orthogonalized with respect to scores on the Social and Governance pillars.

\begin{tabular}{lrrr}
\hline & $\Delta \ln ($ Emissions $)$ & $\Delta \ln ($ Emissions $)$ & $\Delta \ln ($ Emissions $)$ \\
\hline Environment (orth.) & -0.5 & 0.2 & 0.7 \\
& $(0.49)$ & $(0.53)$ & $(0.48)$ \\
\hline Year fixed effects & $\mathrm{Y}$ & $\mathrm{Y}$ & $\mathrm{Y}$ \\
Country fixed effects & $\mathrm{N}$ & $\mathrm{Y}$ & $\mathrm{N}$ \\
Firm fixed effects & $\mathrm{N}$ & $\mathrm{N}$ & $\mathrm{Y}$ \\
Firm controls & $\mathrm{Y}$ & $\mathrm{Y}$ & $\mathrm{Y}$ \\
Country controls & $\mathrm{Y}$ & 0.18 & 0.34 \\
$R^{2}$ (within) & 0.10 & 683 & 683 \\
Firm-years & 683 & 52 & 52 \\
Firms & 52 & 20 & 20 \\
Countries & 20 & & \\
\hline
\end{tabular}


Table A.5: Different timing for emissions growth

Notes: This table repeats the analysis in Panel A of Table 1, but varies the timing of the dependent variable. Panels A, B, C, and D respectively use the dependent variable two years later, one year later, one year ago, and two years ago.

Panel A: Emissions two years later

\begin{tabular}{lrrr}
\hline & $\Delta \ln (\text { Emissions })_{t+2}$ & $\Delta \ln (\text { Emissions })_{t+2}$ & $\Delta \ln (\text { Emissions })_{t+2}$ \\
\hline Overall ESG Score & $-1.2^{* * *}$ & $-0.8^{*}$ & -0.6 \\
& $(0.32)$ & $(0.38)$ & $(0.47)$ \\
\hline Year fixed effects & $\mathrm{Y}$ & $\mathrm{Y}$ & $\mathrm{Y}$ \\
Country fixed effects & $\mathrm{N}$ & $\mathrm{Y}$ & $\mathrm{N}$ \\
Firm fixed effects & $\mathrm{N}$ & $\mathrm{N}$ & $\mathrm{Y}$ \\
Firm controls & $\mathrm{Y}$ & $\mathrm{Y}$ & $\mathrm{Y}$ \\
Country controls & $\mathrm{Y}$ & 0.19 & 0.32 \\
$R^{2}$ (within) & 0.14 & 631 & 631 \\
Firm-years & 631 & 52 & 52 \\
Firms & 52 & 20 & 20 \\
Countries & 20 & & \\
\hline
\end{tabular}

Panel B: Emissions one year later

\begin{tabular}{lrrr}
\hline & $\Delta \ln (\text { Emissions })_{t+1}$ & $\Delta \ln {\text { (Emissions })_{t+1}}$ & $\Delta \ln (\text { Emissions })_{t+1}$ \\
\hline Overall ESG Score & $-1.1^{* *}$ & -0.4 & -0.0 \\
& $(0.39)$ & $(0.41)$ & $(0.50)$ \\
\hline Year fixed effects & $\mathrm{Y}$ & $\mathrm{Y}$ & $\mathrm{Y}$ \\
Country fixed effects & $\mathrm{N}$ & $\mathrm{Y}$ & $\mathrm{N}$ \\
Firm fixed effects & $\mathrm{N}$ & $\mathrm{N}$ & $\mathrm{Y}$ \\
Firm controls & $\mathrm{Y}$ & $\mathrm{Y}$ & $\mathrm{Y}$ \\
Country controls & $\mathrm{Y}$ & 0.19 & $\mathrm{Y}$ \\
$R^{2}($ within $)$ & 0.12 & 683 & 683 \\
Firm-years & 683 & 52 & 52 \\
Firms & 52 & 20 & 20 \\
Countries & 20 & & \\
\hline
\end{tabular}


Panel C: Emissions one year ago

\begin{tabular}{lrrr}
\hline & $\Delta \ln \left(\right.$ Emissions $_{t-1}$ & $\Delta \ln {\text { (Emissions })_{t-1}}$ & $\Delta \ln \left(\right.$ Emissions $_{t-1}$ \\
\hline Overall ESG Score & $-1.1^{* *}$ & -0.6 & -0.4 \\
& $(0.39)$ & $(0.45)$ & $(0.50)$ \\
\hline Year fixed effects & $\mathrm{Y}$ & $\mathrm{Y}$ & $\mathrm{Y}$ \\
Country fixed effects & $\mathrm{N}$ & $\mathrm{Y}$ & $\mathrm{N}$ \\
Firm fixed effects & $\mathrm{N}$ & $\mathrm{N}$ & $\mathrm{Y}$ \\
Firm controls & $\mathrm{Y}$ & $\mathrm{Y}$ & $\mathrm{Y}$ \\
Country controls & $\mathrm{Y}$ & 0.16 & 0.33 \\
$R^{2}($ within $)$ & 0.10 & 682 & 682 \\
Firm-years & 682 & 52 & 52 \\
Firms & 52 & 20 & 20 \\
Countries & 20 & & \\
\hline
\end{tabular}

Panel D: Emissions two years ago

\begin{tabular}{lrrr}
\hline & $\Delta \ln (\text { Emissions })_{t-2}$ & $\Delta \ln \left(\right.$ Emissions $_{t-2}$ & $\Delta \ln \left(\right.$ Emissions $_{t-2}$ \\
\hline Overall ESG Score & $-1.0^{*}$ & -0.1 & 0.7 \\
& $(0.55)$ & $(0.67)$ & $(0.98)$ \\
\hline Year fixed effects & $\mathrm{Y}$ & $\mathrm{Y}$ & $\mathrm{Y}$ \\
Country fixed effects & $\mathrm{N}$ & $\mathrm{Y}$ & $\mathrm{N}$ \\
Firm fixed effects & $\mathrm{N}$ & $\mathrm{N}$ & $\mathrm{Y}$ \\
Firm controls & $\mathrm{Y}$ & $\mathrm{Y}$ & $\mathrm{Y}$ \\
Country controls & $\mathrm{Y}$ & 0.11 & 0.22 \\
$R^{2}($ within $)$ & 0.06 & 681 & 681 \\
Firm-years & 681 & 52 & 52 \\
Firms & 52 & 20 & 20 \\
Countries & 20 & & \\
\hline
\end{tabular}


Table A.6: The level of emissions and the overall ESG score and its pillars

Notes: This table repeats specifications similar to those presented in Table 1, but uses the log level of emissions as the dependent variable.

Panel A: Overall ESG score

\begin{tabular}{lrrr}
\hline & $\ln$ (Emissions) & $\ln$ (Emissions) & $\ln$ (Emissions) \\
\hline Overall ESG Score & $0.20^{* *}$ & 0.11 & 0.03 \\
& $(0.08)$ & $(0.08)$ & $(0.04)$ \\
\hline Year fixed effects & $\mathrm{Y}$ & $\mathrm{Y}$ & $\mathrm{Y}$ \\
Country fixed effects & $\mathrm{N}$ & $\mathrm{Y}$ & $\mathrm{N}$ \\
Firm fixed effects & $\mathrm{N}$ & $\mathrm{N}$ & $\mathrm{Y}$ \\
Firm controls & $\mathrm{Y}$ & $\mathrm{Y}$ & $\mathrm{Y}$ \\
Country controls & $\mathrm{Y}$ & 0.75 & 0.95 \\
$R^{2}$ (within) & 0.44 & 683 & 683 \\
Firm-years & 683 & 52 & 52 \\
Firms & 52 & 20 & 20 \\
Countries & 20 & & \\
\hline
\end{tabular}

Panel B: Scores on individual pillars

\begin{tabular}{lrrr}
\hline & $\ln$ (Emissions) & $\ln$ (Emissions) & $\ln$ (Emissions) \\
\hline Environment & 0.03 & & \\
& $(0.04)$ & 0.04 & \\
Governance & & $(0.02)$ & -0.01 \\
& & & $(0.02)$ \\
Social & & & $\mathrm{Y}$ \\
& & $\mathrm{Y}$ & $\mathrm{Y}$ \\
Year fixed effects & $\mathrm{Y}$ & $\mathrm{Y}$ & $\mathrm{Y}$ \\
Firm fixed effects & $\mathrm{Y}$ & $\mathrm{Y}$ & $\mathrm{Y}$ \\
Firm controls & $\mathrm{Y}$ & $\mathrm{Y}$ & 0.95 \\
Country controls & $\mathrm{Y}$ & 0.95 & 683 \\
$R^{2}$ (within) & 0.95 & 683 & 52 \\
Firm-years & 683 & 52 & 20 \\
Firms & 52 & 20 & \\
Countries & 20 & & \\
\hline
\end{tabular}


Table A.7: Emissions growth and overall ESG score (full sample)

Notes: This table repeats the analysis in Panel A of Table 1 for the full sample of firms available to us, not just those for which we have at least 10 years of data.

\begin{tabular}{lrrr}
\hline & $\Delta \ln ($ Emissions $)$ & $\Delta \ln ($ Emissions $)$ & $\Delta \ln ($ Emissions $)$ \\
\hline Overall ESG Score & $-1.2^{* * *}$ & $-0.8^{*}$ & -0.5 \\
& $(0.36)$ & $(0.43)$ & $(0.52)$ \\
\hline Year fixed effects & $\mathrm{Y}$ & $\mathrm{Y}$ & $\mathrm{Y}$ \\
Country fixed effects & $\mathrm{N}$ & $\mathrm{Y}$ & $\mathrm{N}$ \\
Firm fixed effects & $\mathrm{N}$ & $\mathrm{N}$ & $\mathrm{Y}$ \\
Firm controls & $\mathrm{Y}$ & $\mathrm{Y}$ & $\mathrm{Y}$ \\
Country controls & $\mathrm{Y}$ & 0.20 & 0.37 \\
$R^{2}($ within) & 0.13 & 721 & 721 \\
Firm-years & 721 & 58 & 58 \\
Firms & 58 & 23 & 23 \\
Countries & 23 & & \\
\hline
\end{tabular}


Table A.8: Emissions growth and overall ESG score (not winsorized)

Notes: This table repeats the analysis in Panel A of Table 1 without winsorizing any variables.

\begin{tabular}{lrrr}
\hline & $\Delta \ln ($ Emissions $)$ & $\Delta \ln ($ Emissions $)$ & $\Delta \ln ($ Emissions $)$ \\
\hline Overall ESG Score & $-1.3^{*}$ & -0.6 & -0.6 \\
& $(0.59)$ & $(0.53)$ & $(0.90)$ \\
\hline Year fixed effects & $\mathrm{Y}$ & $\mathrm{Y}$ & $\mathrm{Y}$ \\
Country fixed effects & $\mathrm{N}$ & $\mathrm{Y}$ & $\mathrm{N}$ \\
Firm fixed effects & $\mathrm{N}$ & $\mathrm{N}$ & $\mathrm{Y}$ \\
Firm controls & $\mathrm{Y}$ & $\mathrm{Y}$ & $\mathrm{Y}$ \\
Country controls & $\mathrm{Y}$ & 0.15 & 0.26 \\
$R^{2}($ within $)$ & 0.08 & 683 & 683 \\
Firm-years & 683 & 52 & 52 \\
Firms & 52 & 20 & 20 \\
Countries & 20 & & \\
\hline
\end{tabular}


Table A.9: Growth in emissions intensity and Environment and Governance pillars

Notes: This table repeats the analysis in Panel A of Table 1, but shows emissions intensity instead. The dependent variable in Panel $\mathrm{A}$ is the change in emissions scaled by revenue relative to emissions scaled by revenue in the previous year in percent (multiplied by 100). The dependent variable in Panel B is the change in emissions scaled by assets relative to emissions scaled by assets in the previous year in percent (multiplied by 100).

Panel A: Emissions scaled by revenue

\begin{tabular}{lrrr}
\hline & $\Delta($ Em/Revenue $)$ & $\Delta($ Em/Revenue $)$ & $\Delta($ Em/Revenue $)$ \\
\hline Overall ESG Score & 0.0 & 0.0 & 0.3 \\
& $(0.51)$ & $(0.85)$ & $(1.19)$ \\
\hline Year fixed effects & $\mathrm{Y}$ & $\mathrm{Y}$ & $\mathrm{Y}$ \\
Country fixed effects & $\mathrm{N}$ & $\mathrm{Y}$ & $\mathrm{Y}$ \\
Firm fixed effects & $\mathrm{N}$ & $\mathrm{Y}$ & $\mathrm{Y}$ \\
Firm controls & $\mathrm{Y}$ & $\mathrm{Y}$ & $\mathrm{Y}$ \\
Country controls & $\mathrm{Y}$ & 0.53 & 0.55 \\
$R^{2}($ within $)$ & 0.51 & 683 & 683 \\
Firm-years & 683 & 52 & 52 \\
Firms & 52 & 20 & 20 \\
Countries & 20 & & \\
\hline
\end{tabular}

Panel B: Emissions scaled by assets

\begin{tabular}{lrrr}
\hline & \multicolumn{1}{c}{$\Delta($ Em/Assets $)$} & $\Delta($ Em/Assets $)$ & -1.4 \\
\hline Overall ESG Score & -0.3 & -0.7 & $(1.05)$ \\
\hline Year fixed effects & $(0.48)$ & $(0.45)$ & $\mathrm{Y}$ \\
Country fixed effects & $\mathrm{Y}$ & $\mathrm{Y}$ & $\mathrm{N}$ \\
Firm fixed effects & $\mathrm{N}$ & $\mathrm{Y}$ & $\mathrm{Y}$ \\
Firm controls & $\mathrm{N}$ & $\mathrm{Y}$ & $\mathrm{Y}$ \\
Country controls & $\mathrm{Y}$ & $\mathrm{Y}$ & $\mathrm{Y}$ \\
$R^{2}$ (within) & $\mathrm{Y}$ & 0.27 & 0.33 \\
Firm-years & 0.24 & 683 & 683 \\
Firms & 683 & 52 & 52 \\
Countries & 52 & 20 & 20 \\
\hline
\end{tabular}


Table A.10: Growth in emissions scaled by revenue and Environment and Governance pillars

Notes: This table repeats the analysis in Table 2 but shows emissions intensity instead. The dependent variable is the change in emissions scaled by revenue relative to emissions scaled by revenue in the previous year in percent (multiplied by 100). Panel A shows the Environment pillar and its components. Panel B shows the Governance pillar and its components.

Panel A: Environment pillar and its components

\begin{tabular}{|c|c|c|c|c|}
\hline & $\Delta($ Em/Revenue $)$ & $\Delta($ Em/Revenue $)$ & $\Delta($ Em/Revenue $)$ & $\Delta($ Em/Revenue $)$ \\
\hline Environment & $\begin{array}{r}1.2 \\
(1.52)\end{array}$ & & & \\
\hline Emissions & & $\begin{array}{r}0.4 \\
(0.94)\end{array}$ & & \\
\hline Resource Use & & & $\begin{array}{r}1.3 \\
(1.42)\end{array}$ & \\
\hline Env. Innovation & & & & $\begin{array}{r}0.1 \\
(0.55) \\
\end{array}$ \\
\hline Year fixed effects & $\mathrm{Y}$ & $\mathrm{Y}$ & $\mathrm{Y}$ & $\mathrm{Y}$ \\
\hline Firm fixed effects & $\mathrm{Y}$ & $\mathrm{Y}$ & $\mathrm{Y}$ & $\mathrm{Y}$ \\
\hline Firm controls & $\mathrm{Y}$ & $\mathrm{Y}$ & Y & $\mathrm{Y}$ \\
\hline Country controls & $\mathrm{Y}$ & $\mathrm{Y}$ & $\mathrm{Y}$ & $\mathrm{Y}$ \\
\hline$R^{2}$ (within) & 0.56 & 0.55 & 0.56 & 0.55 \\
\hline Firm-years & 683 & 683 & 683 & 683 \\
\hline Firms & 52 & 52 & 52 & 52 \\
\hline Countries & 20 & 20 & 20 & 20 \\
\hline
\end{tabular}

Panel B: Government pillar and its components

\begin{tabular}{lrrrr}
\hline & $\Delta($ Em/Revenue $)$ & $\Delta($ Em/Revenue $)$ & $\Delta($ Em/Revenue $)$ & $\Delta($ Em/Revenue $)$ \\
\hline Governance & 0.0 & & & \\
& $(0.87)$ & & & \\
Management & & -0.2 & & \\
& & $(0.80)$ & -0.7 & 1.2 \\
CSR Strategy & & $(0.90)$ & $(0.90)$ \\
& & & & $\mathrm{Y}$ \\
Shareholders & & & $\mathrm{Y}$ \\
& & & $\mathrm{Y}$ & $\mathrm{Y}$ \\
Year fixed effects & $\mathrm{Y}$ & $\mathrm{Y}$ & $\mathrm{Y}$ & 0.56 \\
Firm fixed effects & $\mathrm{Y}$ & $\mathrm{Y}$ & $\mathrm{Y}$ & 683 \\
Firm controls & $\mathrm{Y}$ & $\mathrm{Y}$ & 0.55 & 52 \\
Country controls & $\mathrm{Y}$ & $\mathrm{Y}$ & 683 & 20 \\
$R^{2}$ (within) & 0.55 & 683 & 52 & 20 \\
Firm-years & 683 & 52 & & \\
Firms & 52 & 20 & & \\
Countries & 20 & & & \\
\hline
\end{tabular}


Table A.11: Growth in emissions scaled by assets and Environment and Governance pillars

Notes: This table repeats the analysis in Table 2 but shows emissions intensity instead. The dependent variable is the change in emissions scaled by assets relative to emissions scaled by assets in the previous year in percent (multiplied by 100). Panel A shows the Environment pillar and its components. Panel B shows the Governance pillar and its components.

Panel A: Environment pillar and its components

\begin{tabular}{|c|c|c|c|c|}
\hline & $\Delta($ Em/Assets $)$ & $\Delta($ Em/Assets $)$ & $\Delta($ Em/Assets $)$ & $\Delta($ Em/Assets $)$ \\
\hline Environment & $\begin{array}{r}-1.0 \\
(1.45)\end{array}$ & & & \\
\hline Emissions & & $\begin{array}{r}-0.8 \\
(0.99)\end{array}$ & & \\
\hline Resource Use & & & $\begin{array}{r}0.7 \\
(1.63)\end{array}$ & \\
\hline Env. Innovation & & & & $\begin{array}{r}-0.8 \\
(0.56) \\
\end{array}$ \\
\hline Year fixed effects & $\mathrm{Y}$ & $\mathrm{Y}$ & $\mathrm{Y}$ & $\mathrm{Y}$ \\
\hline Firm fixed effects & $\mathrm{Y}$ & $\mathrm{Y}$ & $\mathrm{Y}$ & $\mathrm{Y}$ \\
\hline Firm controls & $\mathrm{Y}$ & Y & $\mathrm{Y}$ & $\mathrm{Y}$ \\
\hline Country controls & $\mathrm{Y}$ & $\mathrm{Y}$ & $\mathrm{Y}$ & $\mathrm{Y}$ \\
\hline$R^{2}($ within $)$ & 0.28 & 0.28 & 0.28 & 0.28 \\
\hline Firm-years & 683 & 683 & 683 & 683 \\
\hline Firms & 52 & 52 & 52 & 52 \\
\hline Countries & 20 & 20 & 20 & 20 \\
\hline
\end{tabular}

Panel B: Government pillar and its components

\begin{tabular}{lrrrr}
\hline & $\Delta($ Em/Assets $)$ & $\Delta($ Em/Assets $)$ & $\Delta($ Em/Assets $)$ & $\Delta($ Em/Assets $)$ \\
\hline Governance & -0.7 & & & \\
& $(0.82)$ & & & \\
Management & & -0.8 & & \\
& & $(0.64)$ & -0.0 & \\
CSR Strategy & & $(0.86)$ & 0.2 \\
& & & & $(0.90)$ \\
Shareholders & & & & $\mathrm{Y}$ \\
& & & $\mathrm{Y}$ & $\mathrm{Y}$ \\
Year fixed effects & $\mathrm{Y}$ & $\mathrm{Y}$ & $\mathrm{Y}$ & $\mathrm{Y}$ \\
Firm fixed effects & $\mathrm{Y}$ & $\mathrm{Y}$ & $\mathrm{Y}$ & 0.28 \\
Firm controls & $\mathrm{Y}$ & $\mathrm{Y}$ & 0.28 & 683 \\
Country controls & $\mathrm{Y}$ & $\mathrm{Y}$ & 683 & 52 \\
$R^{2}($ within $)$ & 0.28 & 683 & 52 & 20 \\
Firm-years & 683 & 52 & 20 & \\
Firms & 52 & 20 & & \\
Countries & 20 & & & \\
\hline
\end{tabular}


Table A.12: Emissions growth and Social pillar

Notes: This table repeats the analysis in Table 2 but shows scores for the Social pillar and its components instead.

\begin{tabular}{|c|c|c|c|c|c|}
\hline & $\Delta \ln ($ Emissions $)$ & $\Delta \ln ($ Emissions $)$ & $\Delta \ln ($ Emissions $)$ & $\Delta \ln ($ Emissions $)$ & $\Delta \ln ($ Emissions $)$ \\
\hline Social & $\begin{array}{r}-0.3 \\
(0.44)\end{array}$ & & & & \\
\hline Workforce & & $\begin{array}{r}0.4 \\
(0.50)\end{array}$ & & & \\
\hline Community & & & $\begin{array}{r}-0.1 \\
(0.36)\end{array}$ & & \\
\hline Human Rights & & & & $\begin{array}{r}-0.4 \\
(0.28)\end{array}$ & \\
\hline Product Responsibility & & & & & $\begin{array}{c}-0.5^{*} \\
(0.26)\end{array}$ \\
\hline Year fixed effects & $\mathrm{Y}$ & $\mathrm{Y}$ & $\mathrm{Y}$ & $\mathrm{Y}$ & $\mathrm{Y}$ \\
\hline Firm fixed effects & $\mathrm{Y}$ & $\mathrm{Y}$ & $\mathrm{Y}$ & $\mathrm{Y}$ & $\mathrm{Y}$ \\
\hline Firm controls & $\mathrm{Y}$ & $\mathrm{Y}$ & $\mathrm{Y}$ & $\mathrm{Y}$ & $\mathrm{Y}$ \\
\hline Country controls & $\mathrm{Y}$ & $\mathrm{Y}$ & Y & $\mathrm{Y}$ & $\mathrm{Y}$ \\
\hline$R^{2}$ (within) & 0.34 & 0.34 & 0.34 & 0.34 & 0.34 \\
\hline Firm-years & 683 & 683 & 683 & 683 & 683 \\
\hline Firms & 52 & 52 & 52 & 52 & 52 \\
\hline Countries & 20 & 20 & 20 & 20 & 20 \\
\hline
\end{tabular}


Table A.13: Growth in emissions scaled by revenue and Social pillar

Notes: This table repeats the analysis in Appendix Table A.12 but shows emissions intensity instead. The dependent variable is the change in emissions scaled by revenue relative to emissions scaled by revenue in the previous year in percent (multiplied by 100).

\begin{tabular}{|c|c|c|c|c|c|}
\hline & $\Delta($ Em/Revenue $)$ & $\Delta($ Em/Revenue $)$ & $\Delta($ Em/Revenue $)$ & $\Delta($ Em/Revenue $)$ & $\Delta($ Em/Revenue $)$ \\
\hline Social & $\begin{array}{r}-0.4 \\
(0.86)\end{array}$ & & & & \\
\hline Workforce & & $\begin{array}{r}0.4 \\
(1.01)\end{array}$ & & & \\
\hline Community & & & $\begin{array}{r}0.3 \\
(0.85)\end{array}$ & & \\
\hline Human Rights & & & & $\begin{array}{r}-0.9 \\
(0.65)\end{array}$ & \\
\hline Product Responsibility & & & & & $\begin{array}{r}-0.1 \\
(0.81) \\
\end{array}$ \\
\hline Year fixed effects & $\mathrm{Y}$ & $\mathrm{Y}$ & $\mathrm{Y}$ & $\mathrm{Y}$ & $\mathrm{Y}$ \\
\hline Firm fixed effects & $\mathrm{Y}$ & $\mathrm{Y}$ & $\mathrm{Y}$ & $\mathrm{Y}$ & $\mathrm{Y}$ \\
\hline Firm controls & $\mathrm{Y}$ & Y & Y & Y & $\mathrm{Y}$ \\
\hline Country controls & Y & $\mathrm{Y}$ & $\mathrm{Y}$ & $\mathrm{Y}$ & $\mathrm{Y}$ \\
\hline$R^{2}($ within $)$ & 0.55 & 0.55 & 0.55 & 0.55 & 0.55 \\
\hline Firm-years & 683 & 683 & 683 & 683 & 683 \\
\hline Firms & 52 & 52 & 52 & 52 & 52 \\
\hline Countries & 20 & 20 & 20 & 20 & 20 \\
\hline
\end{tabular}


Table A.14: Growth in emissions scaled by assets and Social pillar

Notes: This table repeats the analysis in Appendix Table A.12 but shows emissions intensity instead. The dependent variable is the change in emissions scaled by assets relative to emissions scaled by assets in the previous year in percent (multiplied by 100).

\begin{tabular}{|c|c|c|c|c|c|}
\hline & $\Delta($ Em/Assets $)$ & $\Delta($ Em/Assets $)$ & $\Delta($ Em/Assets $)$ & $\Delta($ Em/Assets $)$ & $\Delta(E m / A s s e t s)$ \\
\hline Social & $\begin{array}{c}-2.1^{*} \\
(1.06)\end{array}$ & & & & \\
\hline Workforce & & $\begin{array}{r}0.3 \\
(0.88)\end{array}$ & & & \\
\hline Community & & & $\begin{array}{r}-0.2 \\
(1.02)\end{array}$ & & \\
\hline Human Rights & & & & $\begin{array}{c}-2.3^{* *} \\
(0.98)\end{array}$ & \\
\hline Product Responsibility & & & & & $\begin{array}{r}-1.3 \\
(0.78) \\
\end{array}$ \\
\hline Year fixed effects & $\mathrm{Y}$ & $\mathrm{Y}$ & $\mathrm{Y}$ & $\mathrm{Y}$ & $\mathrm{Y}$ \\
\hline Firm fixed effects & $\mathrm{Y}$ & $\mathrm{Y}$ & $\mathrm{Y}$ & $\mathrm{Y}$ & $\mathrm{Y}$ \\
\hline Firm controls & $\mathrm{Y}$ & Y & $\mathrm{Y}$ & Y & $\mathrm{Y}$ \\
\hline Country controls & Y & $\mathrm{Y}$ & $\mathrm{Y}$ & $\mathrm{Y}$ & $\mathrm{Y}$ \\
\hline$R^{2}$ (within) & 0.28 & 0.28 & 0.28 & 0.29 & 0.28 \\
\hline Firm-years & 683 & 683 & 683 & 683 & 683 \\
\hline Firms & 52 & 52 & 52 & 52 & 52 \\
\hline Countries & 20 & 20 & 20 & 20 & 20 \\
\hline
\end{tabular}

